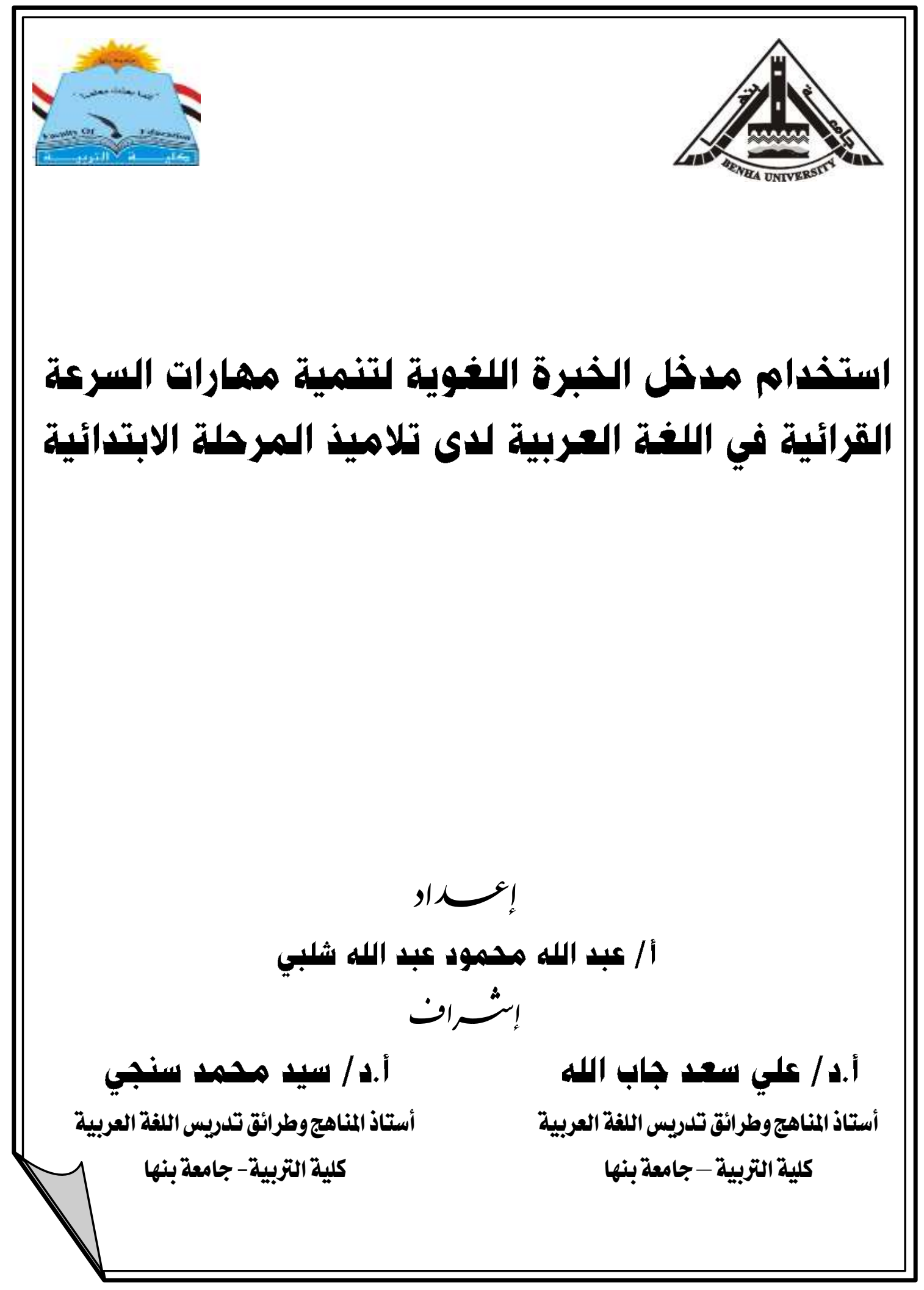




\section{استذام مدخل الخبرة اللغوية لتنمية مهارات السرعة القرائية في اللغة العربية لدى تلاميذ المرحلة الابتائية}<smiles>[AlH2]C[AlH2]</smiles>

أ. أ.د/ /يد محمد سنجي

أستاذ المناهج وطرائق تدريس اللفة العربية

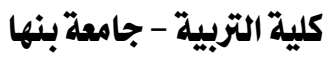

عبد الله محمود عبد الله ثلبي

أ.د / علي سعد جاب الله

أستاذ المناهج وطر ائق تلدريس اللفة العربية

كلية التربية - جامعة بنها تلفية

\section{الملاخـــص العربــي}

هدف البحث الحالي إلى بيان فاعلية استخدام مدخل الخبرة اللغوية في تتمية مهارات

السرعة القرائية لدى تلاميذ المرحلة الابتدائية؛ وللتحقق من ذلك أعد الباحث قائمسة بمهارات السرعة القرائية المناسبة لتلاميذ الصف الخـامس الابتدائي، واختبارًا لمهارات السرعة القرائية وبرنامجًا قائمًا على مدخل الخبرة اللغوية لتتمية تلك المهارات، ولتتفيذ البرنامج اختار الباحث

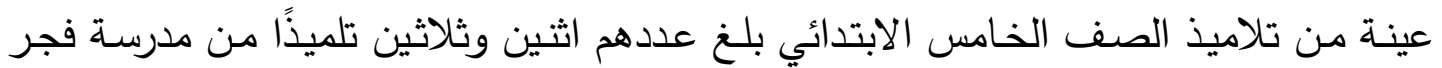

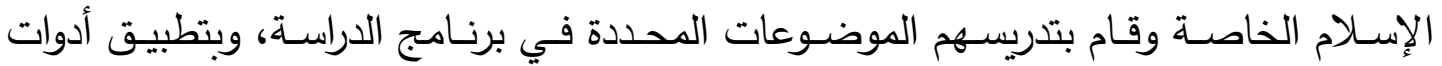

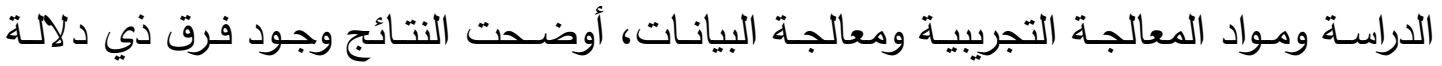
إحصـائية بين متوسطي درجـات التلاميذ في مهارات السرعة القرائية عند مستوى (1 .,.) لاختبار السرعة القرائية قبليًا وبعديًا لصـالح التطبيق البعدي؛ ممـا يؤكد فاعلية مدخل الخبرة الغوية في تتمية مهارات السرعة لدى تلاميذ المرحلة الابتدائية، وأوصت الدراسة باستخدام مدخل الخبرة اللغوية في تتمية مهارات الاستماع والتحدث لاى تلاميذ المرحلة الابتدائية: الكلمات المفتاحية:مدخل الخبرة اللغوية - مهارات السرعة القرائية - تلاميذ المرحلة الابتدائية. 


\section{Using the Language Experience Approach in developing} speed reading skills for primary school pupils.

\section{Study Summary}

The aim of the current research is to demonstrate the effectiveness of using the language experience approach in developing speed reading skills for primary school pupils. To achieve this goal, the researcher has chosen a sample of thirty-five primary students from Fajr Al Islam Private School. To verify the effectiveness of the entrance, the researcher has prepared a list of skills speed Reading suitable for fifth grade primary students, a program based on the entrance to language experience to develop those skills, a test of reading speed skills, and the application of study tools, experimental processing materials and data processing, the results showed and the atmosphere D is a statistically significant difference between the average pupils' scores in reading speed skills at $(0,01)$ level for pre and post reading speed test in favor of post-implementation, which confirms the effectiveness of the language experience approach in developing speed skills for primary school pupils, and recommended the use of the language experience approach in Developing listening and speaking skills for primary school pupils.

Key words: The language experience approach- Speed Reading skills primary school pupils. 


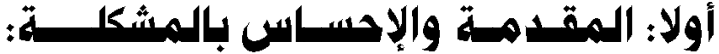

القراءة هي أهم وسائل التعلم الإنساني، من خلالها يكتسب الإنسان العديد من المعارف والعلوم والأفكار، ويطلع على الفكر الإنساني باتساعه وعمقه، فهي تثري خبراته، وتوسع أفقه، وتربطه بماضي أمته، وتجعله قادرًا على فهم حاضره والتخطيط لمستقبله. وتـزداد أهميـة القـراءة في المجتمعـات بزيـادة تعقدها، فكلمـا تعقدـت الثقافـة وازدادت الاختراعات والابتكارات، زادت أهمية القراءة، ومـع زيـادة وسـائل الاتصـال الثقافي المتمثلة في الإذاعـة والتليفزيـون وعـالم الانترنت تبقى القراءة الأداة الأساسية للنمو الشخصسي والاجتمـاعي والثقافي، مـن النواحي الفكريـة والوجدانيـة والعمليـة. (رشدي طعيمـة، 99 (أ، ـ 9)، حيث إن معظم مـا نتعلمـه مـن معلومـات يـأتي عـن طريـق القراءة سـواء أكانـت مـن مـادة مطبوعـة أم إلكترونية؛ لذا فالنجاح في الحياة العملية والعلمية والثقافية والروحية وغير ذلك من جوانب الحياة

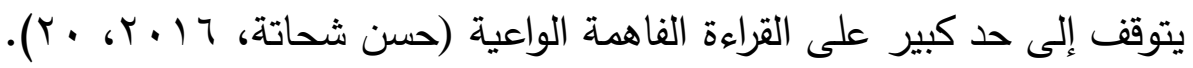
وإذا كانـت القراءة بهذه الأهميـة في حيـاة الفرد والمجتمـع، فـإن أهميتها تزداد بالنسبة للتلاميذ في مراحل التعليم المختلفة وبخاصة المرحلة الابتدائية، لأنه من خلالها يتكون الرصيد اللغوي للتلميذ، وهو الرصيد الذي يُعتمد عليه في المراحل التعليمية التالية، بالإضـافة إلى أنها تمهد السبيل له لكي يستوعب ما يقرأ، ويفهم ما يقرأ فهمًا صحيحًا، فيكون له الأثر الإيجابي في تنمية شخصيته وصقلها (نهلة شرف الدين، 10 • ب، ب). والقراءة ليست مهارة آلية بسيطة، إنها عملية ذهنية تأملية تستتد إلى عمليات عقلية عليا. فهي نشاط ينبغي أن يحتوي كل أنماط التفكير والتقويم والحكم والتحليل والتعليل وحل المشكلات، وليست مجرد نشاط بصري ينتهي بتعرف الرموز المطبوعة أو فهم دلالاتها فقط بل نشاط تعلمي فردي دينامي تتأثر فاعليته بالخبرة السـابقة للفرد ورصيده المعرفي وطرائقه في التقكير والبحث، وتتفسم القراءة إلى نوعين: قراءة جهرية وقراءة صامتة (رشدي طعيمة، 91 (ب)، بس ( ). والقراءة الجهريـة تعين التلاميذ على عادات التكلم الصـيحة أمام السامعين، فتحسّن نطقهم وتعبيرهم علاوة على أنها تيسّر للمعلم الكثف عن الأخطاء التي يقع فيها التلاديذ في النطق، وبالتالي

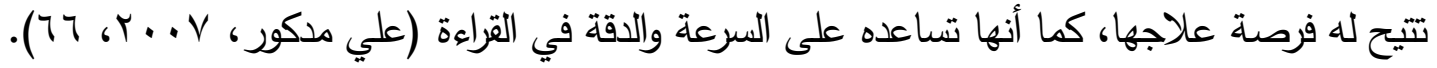
وتظهر أهميـة السـرعة القرائيـة في أنهـا تمكن التلاميذ مـن معرفـة الكلمـات والجمـل والعبارات، والنطق بها نطقًا معبرًا وسلسًا وفهمها بسرعة، مما يتيح لهم مواكبة التطور السريع 
في ميادين المعرفـة المختلفة، وحسن التعامل مـع النصـوص القرائيـة المتتوعـة التي تعترض طريقهم في الكتب الددرسية أو الحياة اليومية العادية.

وتبرز أهمية السرعة في القراءة أيضًا بعد تجاوز التلاميذ الصفوف الأولى من المرحلة

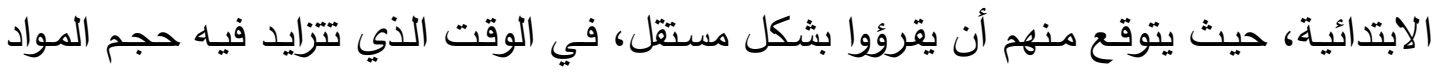

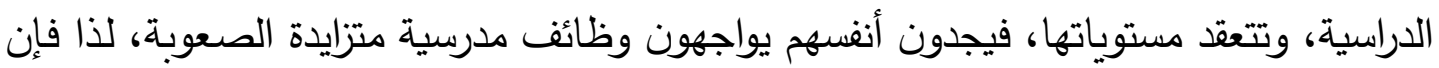

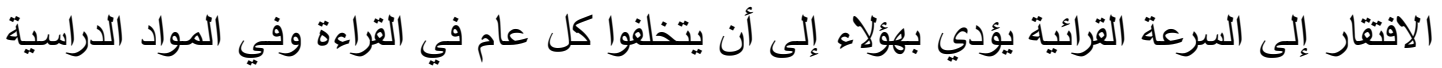
المختلفة (Allington, 1999, 12)، (خالد اللهو، 17 (.ب، ع 9). وكذلك تصبح السرعة القرائية متطلبًا ضروريًا عندما يمارس التلميذ ما يسمى بالقراءة الخاطفة، لتحديد معلومة وردت في فقرة أو صفحة أو تحديد مفردات وفق مؤشر معين، فإن

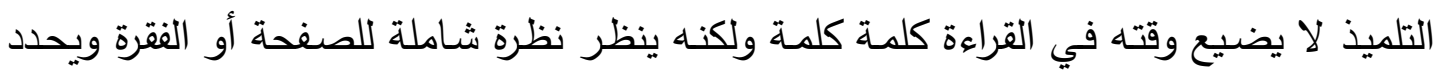

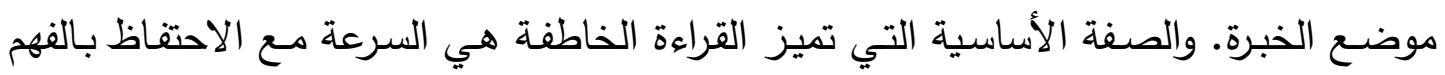

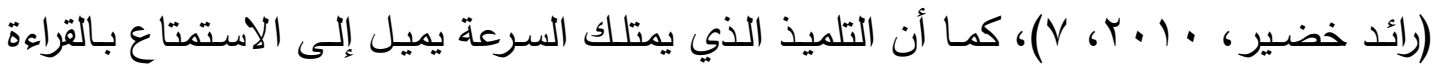
أكثر، وتكون لديه اتجاهات إيجابية نحو القراءة، ومفهوم إيجابي لنفسه كقارئ أكثر من التلميذ التيذ الذي لا يمتلك السرعة في القراءة (15, Oaklym, 2005 ). ومن أفضل طرق تعلم اللغة وتتمية مهاراتها، هو البدء بلغة التلميذ، وأن نجعل منها أساسًا لتعلمه، فالتلميذ الذي يقرأ بسهولة ما هو إلا صاحب خبرة، عرفها وتمثلها، وتجسدت لديه، وأتيحت لله الفرصة قبل القراءة في أن يقص خواطره عن تلك الخبرة، ولذا ينبغي أن يسجل المعلمون أقوال التلاميذ المرتبطة بخبرتهم، حيث تمثل هذه الخبرات مصـادر شغف واهتمام من التلاميذ، لأنهم

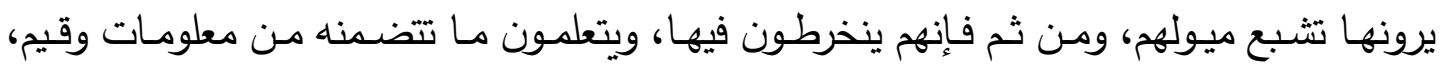

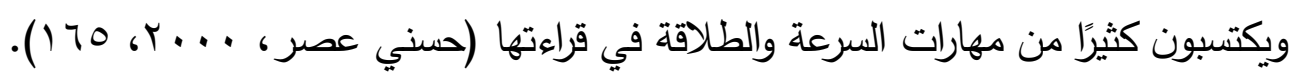

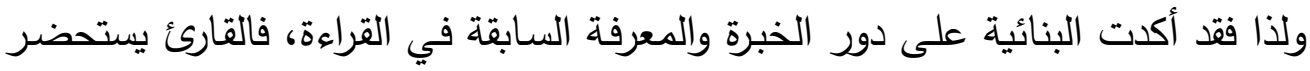

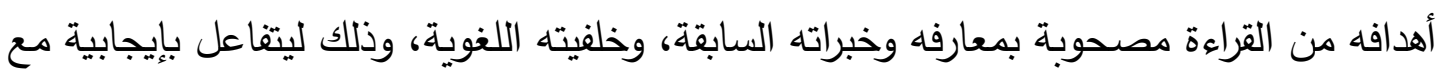
كل الأفكار أو المعاني التي يتضمنها النص الترائي، ثم التراكيب اللغوية والخصائص الأسلوبية ولئه التي يقدم من خلالها. - المان. ومن المداخل التدريسية البنائية التي تعتمد على الخبرة الثخصية للمتعلمين والتكامل

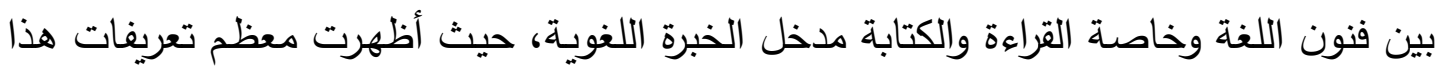
المدخل أنه مدخل تدريسي يعتمد وبشكل أساسي على الخبرات الشخصية للتلاميذ، وعلى لغتهم 
الثفهية في إنتاج مواد لغوية مناسبة، وأنه يؤكد على تكامل فنون اللغة ومهاراتها، فما يستطيع

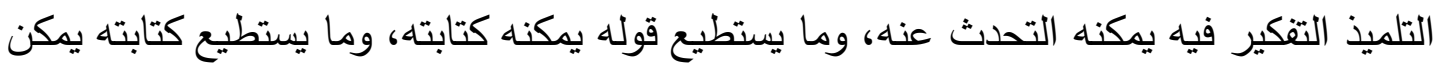

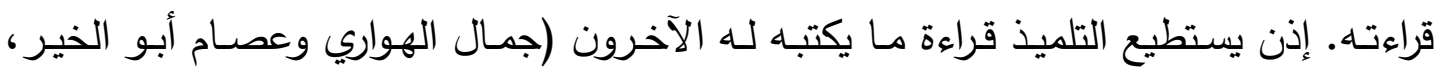

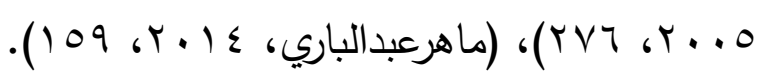

ويعتمد هذا المذخل على خبرات المتعلمين اللغوية السابقة في بناء برامج القراءة، بقصد

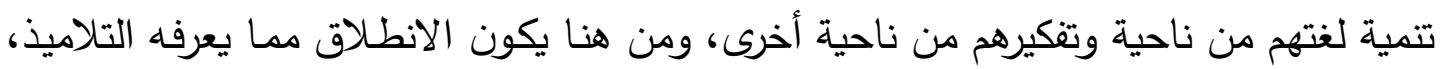
لنبنى عليه مالا يعرفونه، وهو مدخل يمكن استخدامه في تعليم مهارات اللغة المختلفة، فتركز البرامج على التلاميذ والعمل على الإفادة من خبراتهم السابقة في تعليمهم مهارات وموضوعات

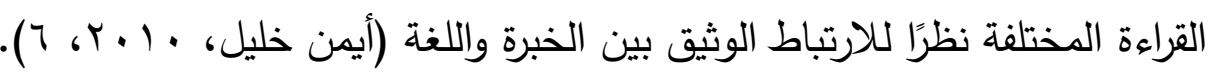

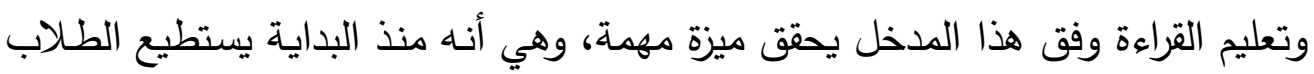

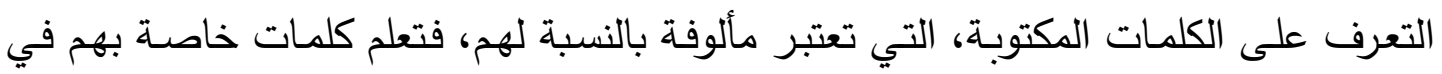

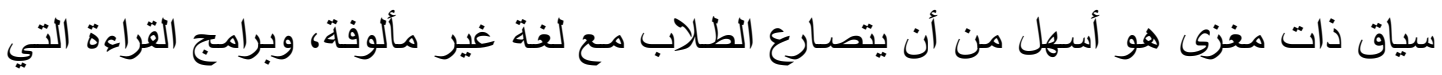

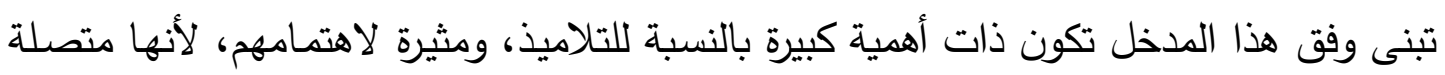

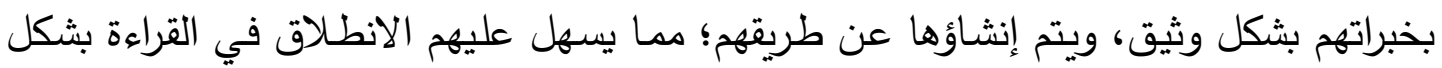
سليم (2, 2008, Nessel\& Dixo). ومن هنا يتضح اهتمام مدخل الخبرة اللغوية بالمحتوى القرائي لما له من دور في تتمية

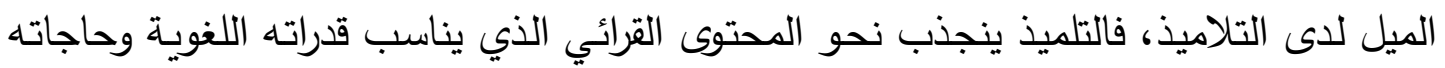

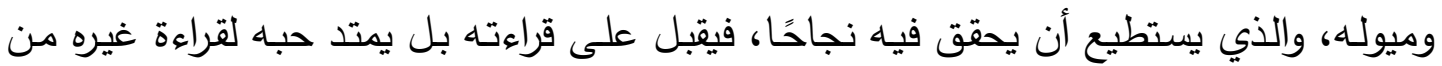

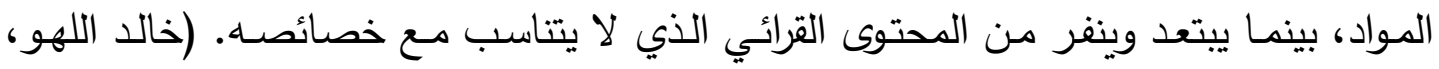

$$
\text { (19-1)، r. } 19
$$

بالرغم من أهميـة مهارات السرعة القرائية في المرحلـة الابتدائية، واهتمـام وزارة التربيـة والتعليم بها إلا أن نتائج الدراسات التي أجريت عليها تثير إلى وجود ضعف لاى تلاميذ المرحلة

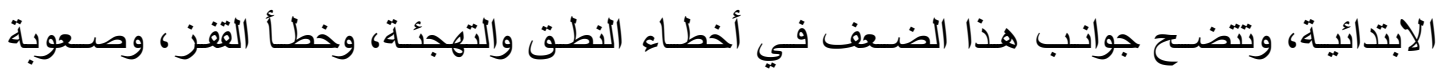

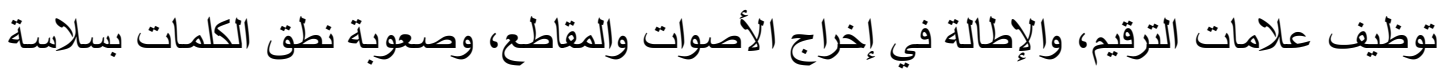

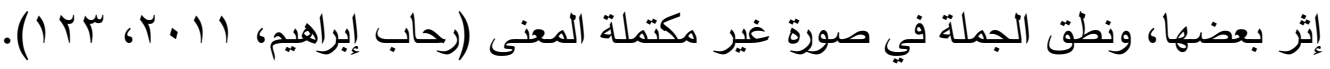


وعلى الجانب الآخر فقت أوصت بعض الدراسات العربية والأجنبية منها: دراسة (جمال

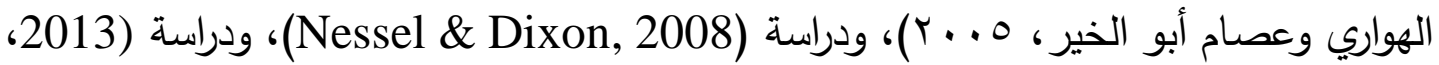
Aboulfotoh باستخدام مدخل الخبرة اللغوية في تعليم التلاميذ القراءة والكتابة في صفوف المرحلة الابتدائية،

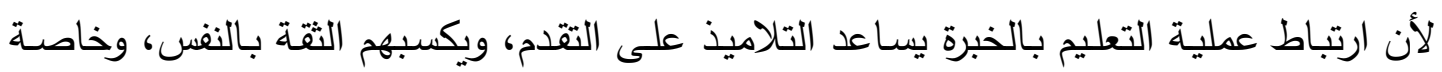

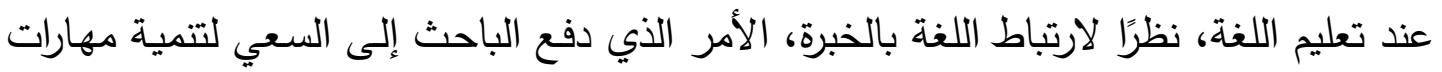
السرعة القرائية لاى تلاميذ المرحلة الابتدائية من خلال استخدام مدخل الخبرة اللغوية.

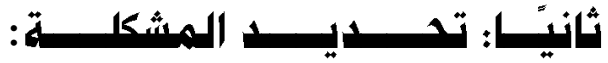

تحددت مشكلة الدراسة الحالية في ضعف تلاميذ المرحلة الابتدائية في مهارات السرعة

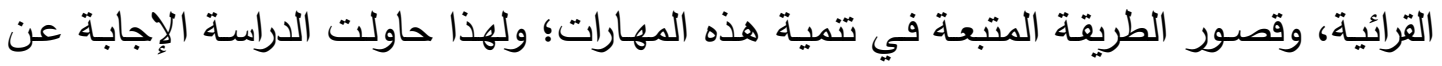

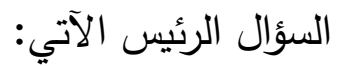

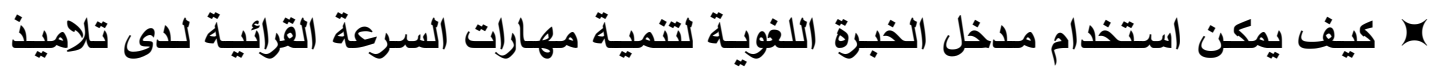

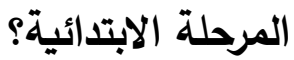

ويتفرع عن هذا السؤال الرئيس الأسئلة الفرعية الآتية:

1- ما مهارات السرعة القرائية المناسبة لتلاميذ المرحلة الابتدائية؟ لهائج

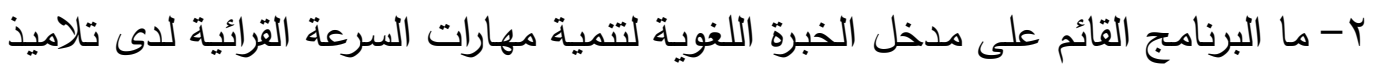

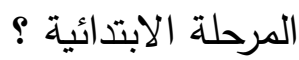

r- ما فاعلية استخدام مدخل الخبرة اللغوية في تتمية مهارات السرعة القرائية لدى تلاميذ

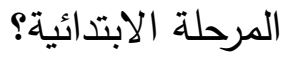

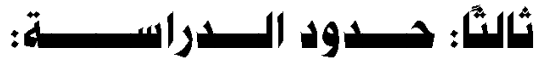 اقتصرت الدراسة الحالية على:}

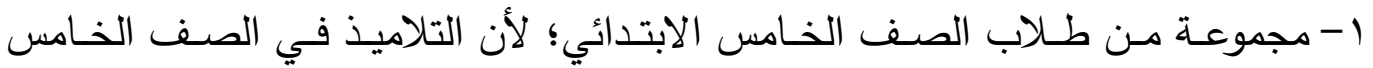
يكونون قد اكتسبوا كثيرًا من مهارات القراءة والكتابة، ويحتاجون إلى الطلاقة في القراءة، ليواكبوا التطور الكمي في المعلومات الدراسية. Y- مهارات السرعة القرائية المناسبة لتلاميذ الصف الخامس الابتدائي التي يصل وزنها

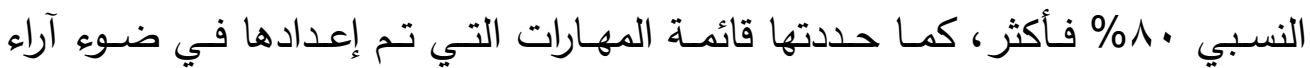

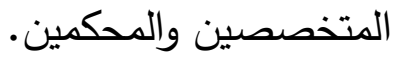


هي إنجاز أكبر قدر من المادة المقروهة في أقل وقت وبجهد يسير ، مع ضرورة الفهم "، أله وبمعنى آخر هي: "السهولة واليسر في أداء عملية القراءة، مع القدرة على فهم المعنى المقروء

.(Blau , 2001 ,28)

وتُعرّف السرعة القرائية إجرائيًا بأنها: قدرة التلاميذ على الانتقال السلس السريع بين

الكلمات المنطوقة مع فهم المقروء واستيعاب تفاصيله، ويقاس ذلك باختبار معدٍّ لهذا الغرض.

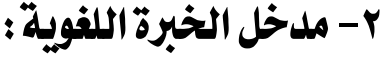

هو مجموعة إجراءات تدريسية تعتمد على اللغة الثفوية النابعة من الخبرات الداخلية والانفعالية الخاصـة بالتلميذ، والتي تقوم على نشاطات قرائية وكتابية تساعد التلميذ على نمو

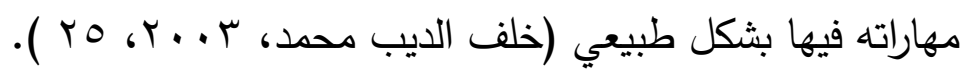

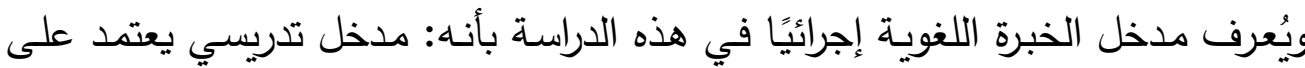

خبرات المتعلمين الشخصية واللغوية في إنشاء مواد قرائية هادفة وممتعة لهم؛ يستطيعون قراءتها بسهولة، والكتابة حول مضمونها بأسلوبهم الخاص؛ وذلك لزيادة طلاقتهم القرائية، وقدرتهم على لقى

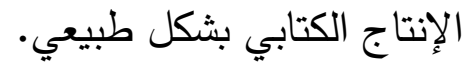

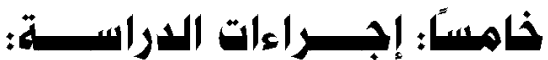

تسير إجراءات الاراسة وفقًا للخطوات الآتية:

1- تعديــ مهـارات السـرعة القرائيسة المناسـبة لتلاميـذ الصـف الخـامس الابتـائي، ويـتم

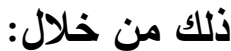

هراسـة الدراسـات السـابقة والأدبيـات ذات الصـلة بموضـوع الدراسـة، وإبراز مـا يمكن

الاستفادة منها.

دراسة أهداف تعليم القراءة ومعاييرها في المرحلة الابتدائية.

• إعداد قائمة مبئية بمهارات السرعة القرائية المناسبة لتلاميذ الصف الخامس الابتدائي.

تعديل القائمة في ضوء آراء المحكمين.

وضع القائمة في صورتها النهائية. 
r - بناء برنامج قائم على مدخل الخبرة اللغويـة لتنمية مهارات السرعة القرائية لدى تلاميذ الصف الخامس الابتدائي وذلك من خلال: أ ـ تحديد الأسس والمعايير التي يبنى في ضونئها البرنـامج القائم على مدخل الخبرة اللغوية من خلال دراسة الأدبيات والداراسات السابقة.

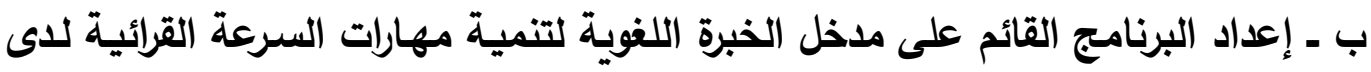
تلاميذ الصف الخامس من خلال: • إعداد الإطار العام للبرنامج في ضوء خطوات ومراحل مدخل الخبرة اللغوية. • • - إعداد كتاب التلميذ. ץ- تحديد فاعلية استخدام مدخل الخبرة اللغويـة لتنمية مهارات السرعة لاى تلاميذ الصف

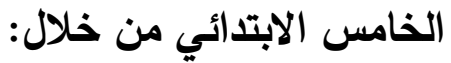
إعداد اختبار مهارات السرعة القرائية لتلاميذ الصف الخامس الابتدائي، وعرضه على الابلى

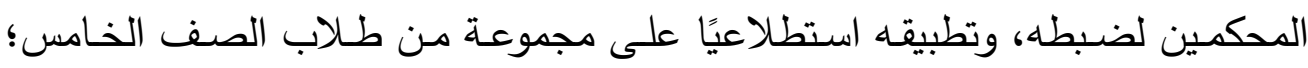

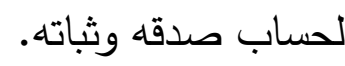
اختيار مجموعة من طلاب الصف الخامس الابتدائي. • تطبيق اختبار مهارات السرعة القرائية على المجموعة قبليًا. تدريس موضوعات البرنامج القائم على مدخل الخبرة اللغوية لتلاميذ المجموعة. • تطبيق اختبار مهارات السرعة القرائية على المجموعة بعديًا. ع - رصد النتائج وتحليلها وتفسيرها. ه - تقديم التوصيات والمقترحات.

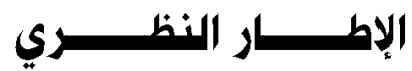

\section{المحور الأول: السرعة القرائية لتلاميذ المرحلة الابتدائية:}

ا- مفهوه السرعة القرائية:

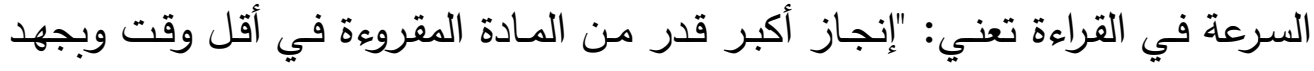

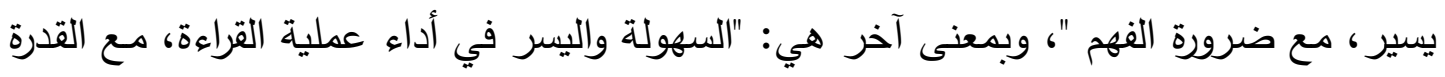
على فهم المعنى المقروء" (28, Blau , 2001 ). وهي ـ أيضًا: الوقت الذي يستغرقه التلميذ الطبيعي 
لإعادة بناء الكلمة في ذهنه، ثم الانتقال إلى الكلمة التي تليها دون أن يترك فترة زمنية ملموسة بينهما

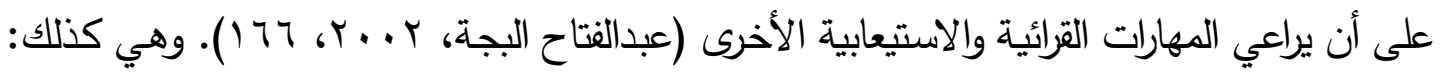
" فهم أكبر كم من المادة المطبوعة فهمًا ناقداً تذوقيًا في أقل وقت ممكن" (محمود الناقة؛ وحيد

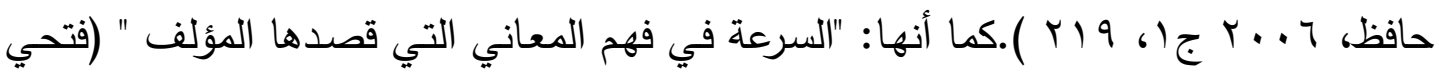

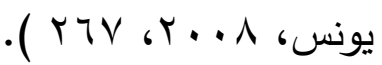

وفي ضوء هذه التعريفات يمكن للباحث أن يعرّف السرعة القرائية إجرائيًا بأنها: قدرة التلاميذ على الانتقال السلس السريع بين الكلمات المنطوقة مع فهم المقروء واستيعاب تفاصيله، ويقاس ذلك باختبار معدٍ لهذا الغرض.

\section{r- أهمية السرعة القرائية:}

السـرعة في القراءة مهارة يجب تتميتها؛ فهي توفر الوقت الذي يمكن استغلاله في

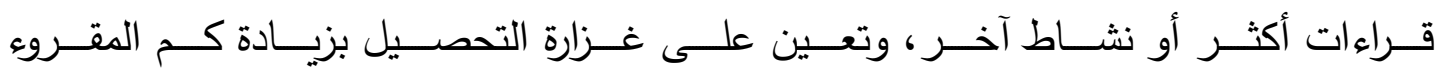
(محمد فضل الله، ع . . Y، T ( )، وتجعل التلميذ قادرًا على مواجهة التضخم المعرفي في عالمنا المعاصر ، كما تساعده أن يستثر الطاقة العقلية التي أمده الله ـ تعالى ـ بها، فتمكنه من التفكير بسرعة وفهم المقروء، حيث إن عدم الفهم يرجع في أحيان كثيرة إلى البطء في القراءة، والتلميذ البطئ في القراءة ربما يتخلف عن الركب، ويعجز عن الوفاء بمتطلبات الدراسـة وما تقتضيه

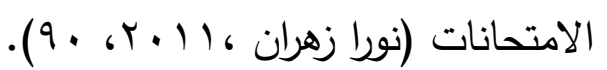

وفي ضوء هذه الأهمية يمكن للباحث أن يحدد أهمية السرعة لتلميذ الصف الخامس

فيما يأتي:

تزيد كم المقروء اليومي لايه؛ مما يمكنه من استيعاب الكم المعرفي الهائل في المواد

الدراسية المختلفة.

تعينه على مواجهة التضخم المعرفي الكبير في هذا العصر •

تتيح لله سرعة التفكير و فهم المقروء واستيعابه بجهد يسير • تهونه

تمكنه من زيادة التحصيل الدراسي، وأداء الامتحانات الحديثة التي تعتمد على السرعة.

تعدّ مقياسًا للحكم على براعته في القراءة، ووسيلة لمراقبة مدى تقدمه فيها.

ب- مستويات السرعة القرائية:

لقـد تعـدت الأراء حـول مسـتويات السـرعة في القـراءة، حيـث يـرى عبـدالغني محمـد

( 99 (، س r أن هناك ثلاثة مستويات، هي: القراءة الخاطفة وهي أعلى مستويات السرعة، 
وتستعمل للحصول على الفكرة العامة للموضوع أو للعثور على أسماء وأرقام محددة في النص

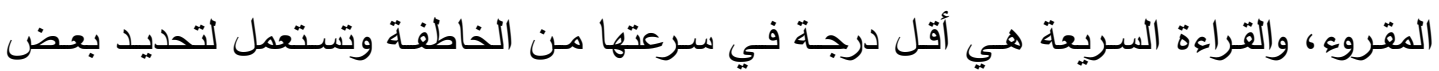

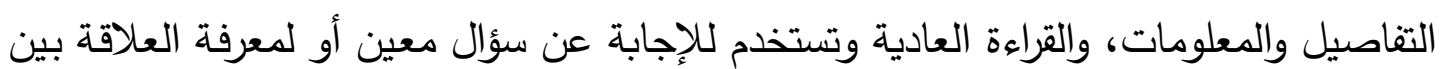

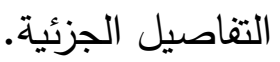

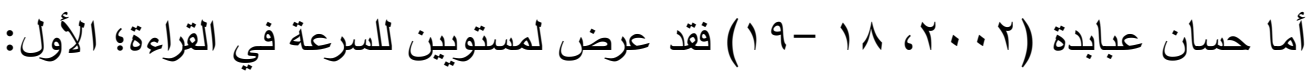
القراءة العاجلة، وتهدف إلى البحث عن معلومة ما بسرعة كالاطلاع على فهارس الكتب وقوائم العناوين والأسماء، والثاني: القراءة السريعة لتكوين فكرة عامة عن موضوع متسع، وهي أكثر لهر دقة من القراءة العاجلة إذ تحتاج إلى سرعة أحيانًا وإلى تأنٍ ووقفات أحيانًا أخرى.

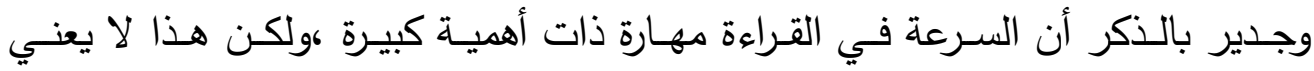
بالضرورة الاحتفاظ بسرعة واحدة في القراءة، بل يجب تنوعها، فالتلميذ الجيد ليس بالضرورة هو

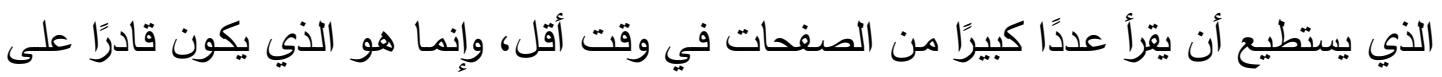
تكييف سرعته في القراءة طبقًا لغرضـه من القراءة، وصعوبة المادة المقروءة ،ونوعها، ودرجة

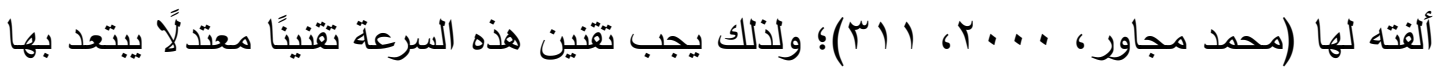
عن البطء الممل والإسراع المخل، ولن يتأتى ذلك سوى بتدريب التلاميذ على أن يكون لديهم مرونة في سرعة القراءة، فالتلميذ الذي لا يستخدم إلا سرعة واحدة في قراءته سوف يواجه الكثير

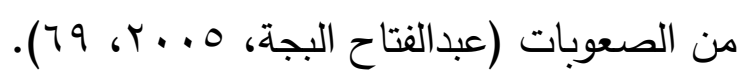

ومن ثمّ فإن الدراسة الحالية ستعتمد على المستوى الثاني من مستويات السرعة وهو القراءة السريعة التي تمكن التلميذ من الوقوف على الأفكار الرئيسة والفرعية للنص القرائي؛ لتحقيق الفهم والاستيعاب في أثناء عملية القراءة. ومن خـلال عرض الدراسـة لمستويات السرعة القرائية، يستطيع الباحث تحديد بعض الأسس التربوية التي ينبغي تتمية مهارات السرعة في ضوئها وفق البرنامج المقترح، وهي:

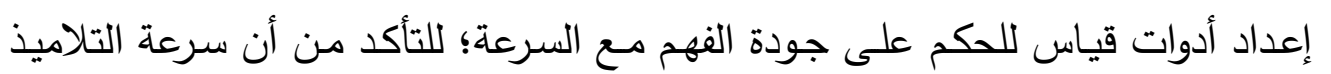
القرائية مصحوبة بالفهم الصحيح لها قُرِئ. تدريب التلاميذ على تتوع السرعة في القراءة وفق الغرض من القراءة ونوعية المقروء. هدريب التلاميذ على القراءة الخاطفة؛ لتحديد الفكرة العامة للنص المقروء. 


\section{§- مهارات السرعة القرائية؛}

حددت كثير من الدراسات السابقة مهارات السرعة في القراءة، ومن هذه الدراسات: - دراسة مروة الجرواني (El-Garawany,2010) التي حددت مهارة السرعة القرائية الآتية: • القراءة بمعدل لا يقل عن ـ إ كلمة في الدقيقة، مع السماح بعشرة أخطاء أو أقل. - دراسة تشانج ( 2012, Chang) التي حددت مهارات السرعة القرائية فيما يأتي: • يقرأ بسرعة مناسبة للمقروء. " يقرأ بمعدل يزيد على .0 ب كلمة في الدقيقة الواحدة. - دراسة شامان معابرة (ع ا ـ r ) التي توصلت إلى مهارات السرعة القرائية الآتية: قراءة الكلمات والجمل بسرعة مناسبة للمقروء. • تحديد الكلمات المفتاحية في النص المقروء في أقل وقت ممكن. - ارتفاع نسبة الاستيعاب القرائي المتحقق للقارئ. - دراسة رزان عياصرة ( 10 • ب ) التي حددت مهارات السرعة القرائية فيما يأتي: • قراءة العدد المحدد من المفردات اللغوية في أقل زمن ممكن. القراءة بسرعة مناسبة.

وفي ضوء ما تم عرضه من دراسات سابقة، يمكن للباحث أن يحدد مهارات السرعة في القراءة المناسبة لتلاميذ الصف الخامس الابتدائي والتي يمكن تنميتها من خلال البرنامج المقترح فيما يأتي: • يقرأ عددًا محددًا من الكلمات في الدقيقة الواحدة. • بقرأ الكلمة دفعة واحدة. ينوّع في سرعة القراءة وفق طبيعة المقروء. يحدد الكلمة المفتاحية في النص المقروء. • يحدد الفكرة الرئيسة للمقروء. • - ل يحدد الأفكار الفرعية للنص المقروء.

\section{ه- معدلات السرعة القرائية؛}

من الضروري عند تعليم مهارات الطلاقة القرائية تحديد المعدل القرائي لمتوسط سرعة تعرف التلاميذ على الكلمات تلقائيًا، في ضوء مستواهم القرائي؛ حتى تتمو لديهم المهارة بصورة 
واقعية ميسرة، ويستطيع المعلم ضبط أداء التلاميذ وتقويمهم وفق هذا المعدل المناسب لهم؛ لذا

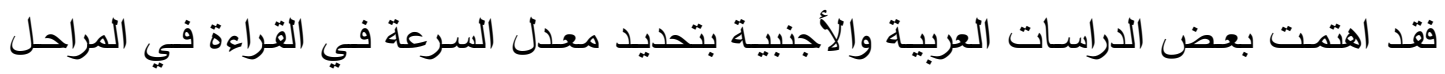

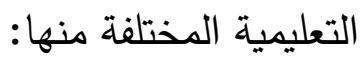
- دراسـة حمدان نصر (1999 (19) واستهدفت معرفة عدد الكلمات التي يستطيع تلميذ نهاية

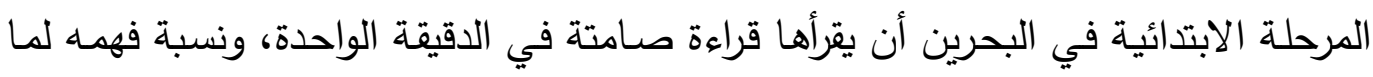

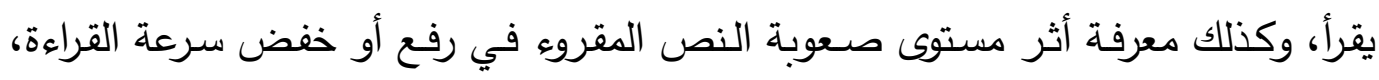

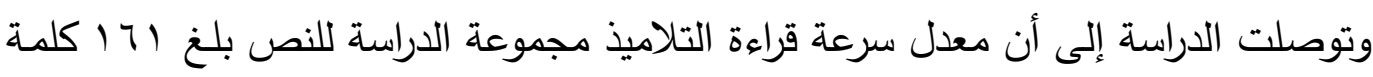

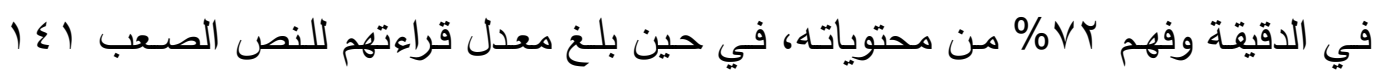

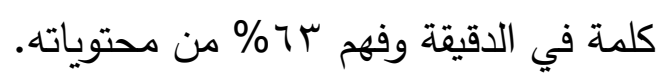

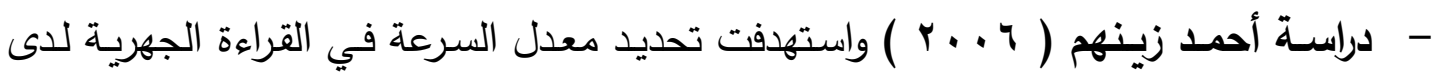

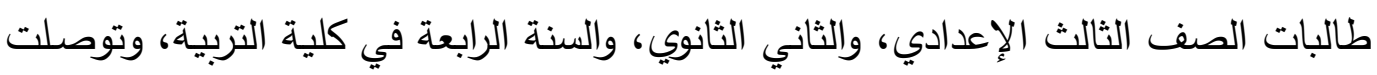

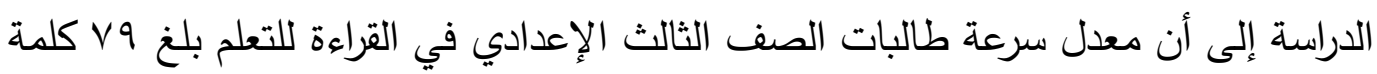

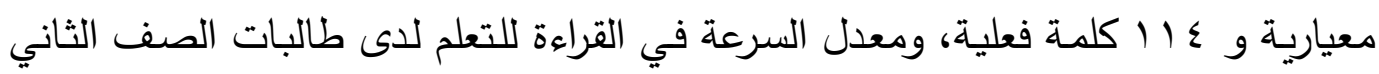

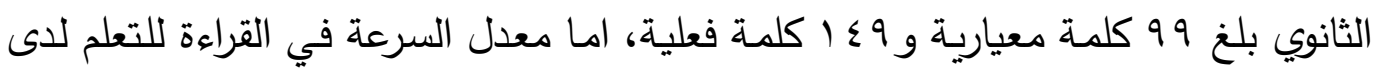

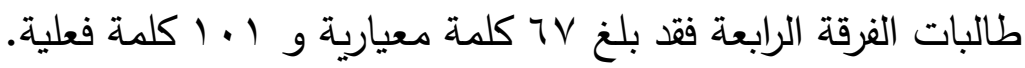

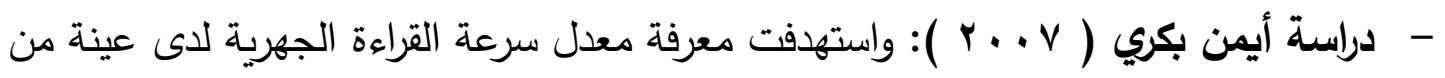
تلاميذ الصف الخامس الابتدائي، وتوصلت الدراسة إلى أن متوسط معدل سرعة القراءة

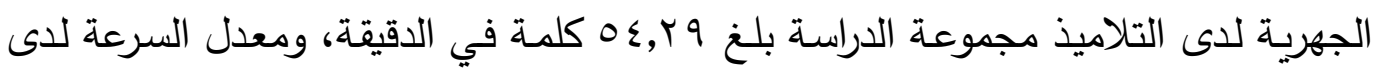

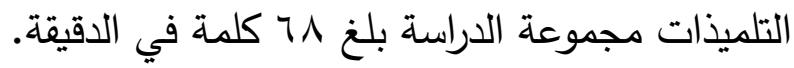

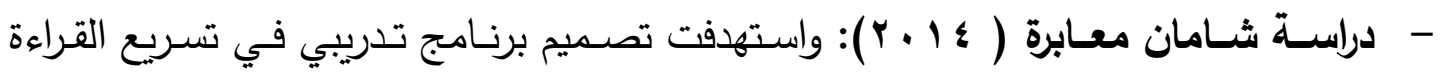
العربية وقياس أثره في زيادة معدل السرعة في القراءة الصامتة، وتحسين الاستيعاب القرائي

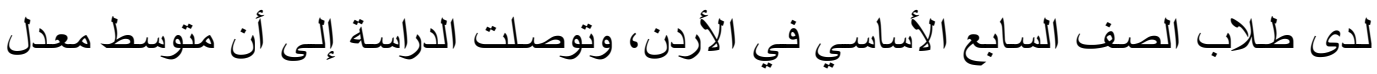

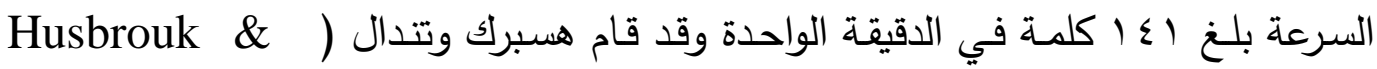

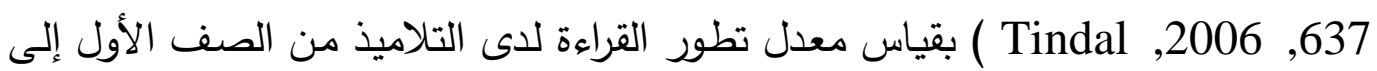

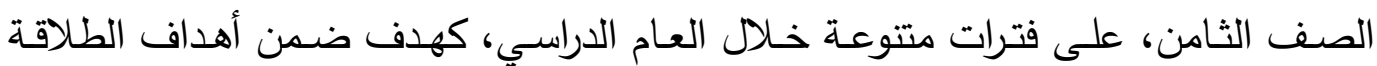
القرائية في نهاية مستوى الصف، وتوصلا إلى ما يلي: 


\begin{tabular}{|c|c|c|c|}
\hline 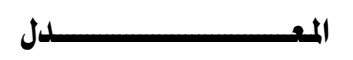 & الصف & 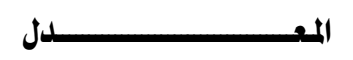 & الصف \\
\hline Yro اكلمة في الدقيقة الواحدة & الخامس & ro كلمة في الدقيقة الواحدة & الأول \\
\hline \$ ا كلمة في الدقيقة الواحدة & السادس & §ه كلمة في الدقيقة الواحدة & الثاني \\
\hline VI ا كلمة في الدقيقة الواحدة & السابع & §|l كلمة في الدقيقة الواحدة & الثالث \\
\hline |Y كلمة في الدقيقة الواحدة & 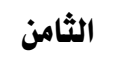 & 1/1 اكلمة في الدقيقة الواحلة & الرابع \\
\hline
\end{tabular}

بينمـا أشـار راسنسكي و باداك ( Rasinski \&Padak,2013, 198 ) إلى تطور معدل النمـو في قراءة الكلمـات في كل صف من الصفوف على مدار العـام الدراسي، وكان

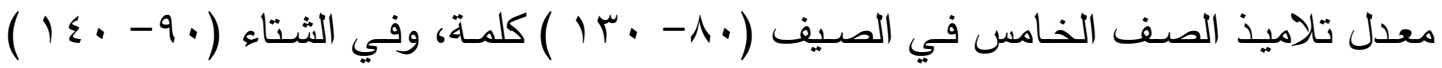
كلمة، وفي الربيع ( . . . . 10 1 ) كلمة. ومـن خـلال عـرض الدراسـات السـابقة يتضـح أن متوســ معـدل سـرعة القـراءة في الدراسات العربية ضـعيف جدًا مقارنـة بمعدل الدراسـات الأجنبية، وإن كان مرتفعًا نوعًا مـا في

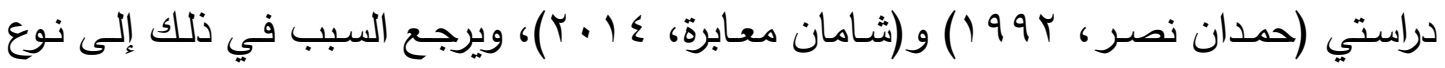
القراءة، حيث إن سرعة التلميذ في القراءة الصـامتة تفوق بكثير سرعته في القراءة الجهريـة؛ لما تتطلبه الثانية من تحكم في الأحبال الصوتية وصحة النطق وحسن التعبير، كما بينت الدراسات السابقة وجود علاقة ارتباطية بين معدل السرعة في القراءة ومستوى صسوبة المقروء من جهة، وبينها وبين مستوى فهم المقروء من جهة أخرى.

\section{Y - طرائق قياس السرعة القرائية :}

تعددت وتتوعت طرائق قياس سرعة القراءة، فقد اقترح ستيف موديل ( . . . ب، 0_ד)

طريقة لقياس السرعة في القراءة تقوم على حساب الوقت المستغرق في القراءة بالثواني، ثم قسمة عدد الكلمات على عدد الثواني ،وضرب الناتج في ستين، ويكون الناتج هو سرعة قراءة الكلمات في الدقيقة الواحدة. بينما حدد لوري روزاكسي ( . . . . ؟ ؟ ( ) طريقة أخرى لحساب السرعة في القراءة، وذلك بتثبيت متغير الوقت دقيقة واحدة، بحيث يضع المتعلم علامة في أول السطر الذي يبدأ القراءة منه، ثم يضـع علامـة أخرى عند انتهاء الدقيقة، وبذلك يتم حساب عدد الكلمات التي قرأها في الدقيقة الواحدة، وهذه الطريقة التي ستعتمد عليها الدراسـة الحالية في حساب معدل قراءة تلاميذ الصف الخامس الابتدائي؛ لسهولة تطبيقها، ودقتها، ومناسبتها للنصوص الكبيرة والصغيرة، وإمكانية تكرراها بسهولة؛ مما يتيح للمعلم الوقوف المستمر على تطور سرعة قراءة التلاميذ. 
وعند قياس سرعة القراءة يجب أن نضع في أذهاننا تلك العلاقة الارتباطية بين الدقة والسرعة؛ ولهذا فقد أثار (137, Miller \& Groff 2008) إلى كيفية حساب المعدل القرائي من خلال عد المعلم الكلمات التي قرأها التلميذ بصورة صحيحة في الدقيقة الواحدة، عند قراءة نص محدد أو صفحة قصيرة ،وتحديد عدد الأخطاء الناتجة عن عملية القراءة، ويتم ذلك من

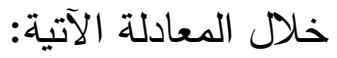

عدد الكلمات الصحيحة المقروءة في الدقيقة الواحدة = العدد الإجمالي للكلمات المقروءة عدد الأخطاء.

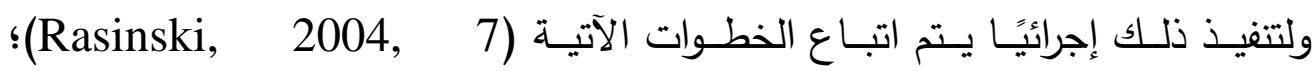

(Duncko, 2013, 197)

اختر قطعة أو عدة قطع تحتوي على •.0 كلمة تقريبًا، في المستوى العمري والتعليمي للتلميذ، ثم تحقق من مقروئية هذه القطع. اطلب من التلميذ قراءة القطعة في دقيقة واحدة، وسجل القراءة. احرص أن يقرأ التلميذ بصوت مرتفع، وبطريقة طبيعية ليست أسرع من الطبيعي. دوّن أية أخطاء يقع فيها التلميذ أثناء القراءة دون تصحيح. كرر الخطوة الأولى والثانيـة على قطع قرائيـة مختلفـة (اختياريًا) وفي حالـة التكرار استخدم المتوسط لدرجات التلميذ. حدد الدقة بتقسيم عدد الكلمات التي قرأها التلميذ بصورة صـيحة في الدقيقة الواحدة على العدد الإجمالي للكلمات المقروء ة؛ ليصبح العدد نسبة مئوية. هدد معدل سـرعة القراءة بحسـاب العدد الكلي للكلمـات المقروءة بشكل صـحيح في الدقيقة الواحدة. ومن المقاييس التي استخدمت لقياس وتحديد المعدل القرائي مع الدقة مقياس طلاقة Curriculum- Based Measurement of Oral القراءة الثفهية المبني على المنهج reading Fluency والدقة القرائية، باستخدام نصوص المنهج ، Husbrouck , Tindal, 2006, 636)، ويتميز هذا المقيـاس بالسرعة والسـهولة في التطبيق، حيث يسـاعد على تقييم الدقة القرائية والمعدل القرائي لدى جميع تلاميذ الفصل في أقل من ساعتين؛ مما يمكّن المعلم من تكرار عملية التقييم عدة مرات على مدار العام؛ لتحديد معدل تقدم النمو القرائي لدى التلاميذ، ومعرفة التلاميذ الذين 
لم يحققوا تقدمًا، ومراقبة تقدمه بشكل دقيق، وقد استخدمت كثير من الدراسـات السـابقة هذا المقياس،منها: دراسة أنجيلا(Angela,2004) ودراسة جنلين (Jenlyn,2012). وسيسترشد الباحث بهذا المقياس عند إعداد اختبار مهارات الطلاقة القرائية المناسب

لتلاميذ الصف الخامس الابتدائي في الدراسة الحالية. ويجب أن ننتبه إلى أن السرعة المقصودة في القراءة ليست سرعة في آليتها فقط بل السرعة في فهم معنى المقروء أيضًا، فلا جدوى من القراءة الدقيقة السريعة دون فهم، والسرعة في القراءة تعد ذات قيمة عندما يحقق بها التلميذ الدرجة نفسها من الفهم لو قرأ ببطء (إبراهيم

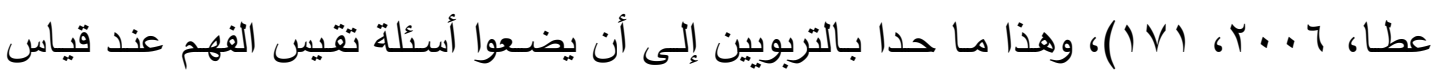
سرعة القراءة؛ لهذا سيحتوى اختبار مهارات السرعة القرائية الذي سيعده الباحث على أسئلة تقيس الفهم للتأكد من أن السرعة في القراءة مصحوبة بالفهم.

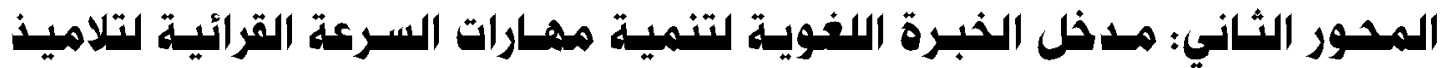
المر حلة الابتدائية.

أولا : مفهوهر ملذخل الخبرة اللفوية :

الخبـرة لغـة: خَبُرَ الأمـر أي عرفـه على حقيقته وجربـه، والخِبرة هي نتـاج مـا مـر بـه

الثـخص مـن أحداث أو رآه أو عانـاه أي مجمـوع تجاربـه وثقافته. و واصـطلاحًا: هـي كـل مـا اكتسبه الشخص من خلال تفاعله مع البيئة المحيطة. والخبرة اللغوية هي ذلك الموقف اللغوي التعليمي الذي يهيأ ويُعد لكي يعايشه التلميذ ويمارس من خلاله استعمال اللغة؛ ليخرج منـه وقد اكتسب مجموعة من المعلومات والمعارف عن اللغة واستخداماتها، ومجموعة من مهارات الاستماع والكلام والقراءة والكتابة، وقدرة على التفكير باللغـة والتعبير عمـا يريد، ومن ثم يكتسب في النهايـة القدرة على استخدام اللغـة في مواقف حقيقية تتفق وأغراضها ودوافعه ( رشدي طعيمه و محمود الناقة، 7 . . ب، به ) ). وهو :" مجموعة إجراءات تدريسية تعتمد على اللغة الثفوية النابعة من الخبرات الداخلية والانفعالية الخاصـة بالتلميذ، والتي تقوم على نشاطات قرائية وكتابية تساعد التلميذ على نمو مهاراته فيها بشكل طبيعي" (خلف الديب محمد، س . . Y، 0 م ). وهو مدخل يقوم على المتعلم، حيث يتم من خلالهه دمه المهارات اللغويـة ،ويقوم على الخبرة الحياتية للمتعلم وتعبيرات البيئة المحيطة التي تظهر في لغته الثفوية؛ لإنشاء نصوص 
قرائية وكتابية ذات معنى؛ لذلك فهو ينمي قدرة التلاميذ على الإبداع من خلال عمليات القراءة والكتابة. (Aboulfotoh,2013,10-11 ) ويُعرَف أيضًا بأنه: "معرفة التلاميذ وملاحظاتهم لعديد من ألفاظ اللغة بأسلوب مكتسب، وعادة يكتسب التلميذ الخبرة من خلال التعامل مع الأسرة والبيئة المحيطة، ويؤدي تكرار هذا التعامل

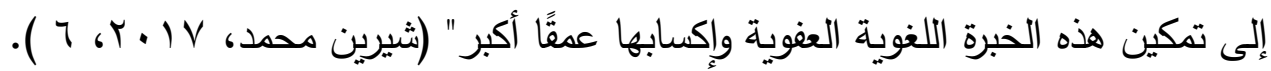
ومـن خـلال عرض التعريفـات السـابقة يتبـين أن مـدخل الخبرة اللغويـة مـذخل بنـائي تدريسي يعتمد بشكل أساسي على خبرات المتعلمين ولغتهم الثخصية في إنثاء مواد القراءة والكتابة أو اختيارها في ضوه خبرتهم؛ لتتمية مهارات اللغة المختلفة بشكل طبيعي من خلال تقديم فرص متعددة للقراءة والكتابة والاستماع والتحدث؛ لذا فهو ينمي القدرة على التأليف والإبداع، ويكسب المتعلمين القدرة على استخدام اللغة استخدامًا وظيفيًا. ويُعرف إجرائيًا في هذه الدراسـة بأنسا: مدخل تدريسي يعتمد على خلى خبرات المتعلمين

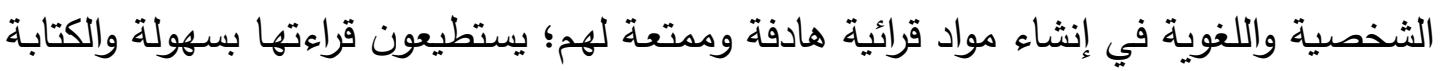

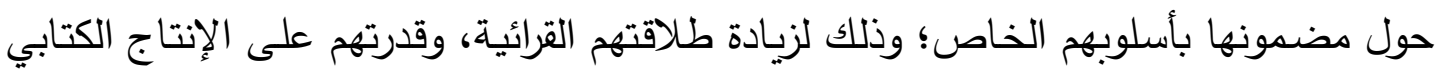
بشكل طبيعي.

\section{ثانيًا : سمات ملاخل الخبرة اللفوية :}

لقد اتسم مدخل الخبرة اللغويـة بمجموعة من السمات والخصائص التي تميزه عن غيره

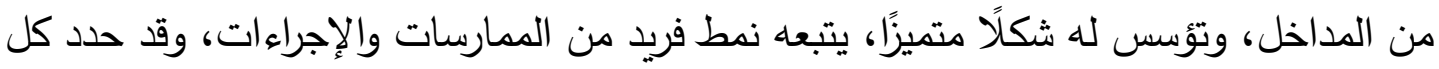

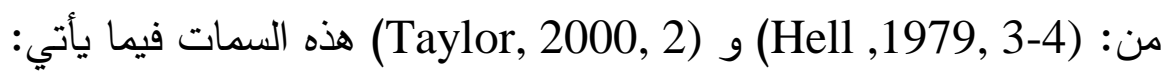
1- يعتمد على خبرات التلاميذ بأشكالها التعبيريـة المختلفة كمواد للقراءة، وهذا لا لا يعني استغناءه عن مواد القراءة الأخرى، التي تستخدم في هذا المدخل بشكل إضافي.

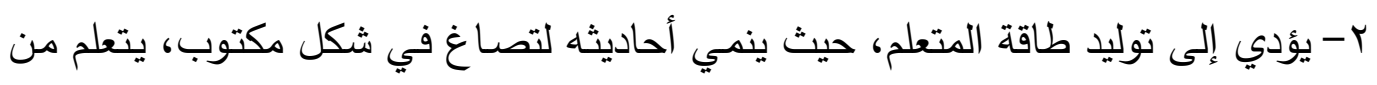

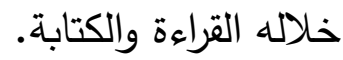

ب- يكامل بين فنون اللغة المختلفة (الاستماع، التحدث، القراءة، الكتابة) فالمتعلم في هذا المدخل تتمو لديه مهاراة التحدث والاستماع، كما تنمو لديه القدرة على القراءة والكتابة والفهم بشكل أساسي. 
؟- يتم تصميم المفردات اللغوية بواسطة المتعلم، فليس هنالك مفردات تتحكم في القراءة إلا مفردات حديثه، ولكن على المعلم ألا يقتصر على مفردات وجمل بعينها تفاديًا للتكرار ه- يُستمد التعلم والتدريس من شخصية المتعلم، ويرتبط بمهارات الاتصال الخاصة به. ד- يعتمد على الابتكارية، وإبداع كل من المعلم والمتعلم؛ فبرنامج القراءة فيه غير محدد. V- تحدد خبرات التلاميذ المحتوى القرائي الذي سيُقدم لهم.

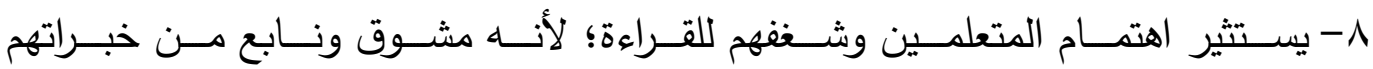
وتجاربهم الشخصية. 9- ينوّع الممارسات للقائمين بالتدريس. • (- يكون التدريس والتعلم من خلال هذا المدخل شخصيًا، واتصاليًا، وابتكاريًا. 1 ا - يؤكد على الجانب الإبداعي؛ حيث يبدع التلميذ في إنتاجه للمواد اللغوية، وتكون ذات

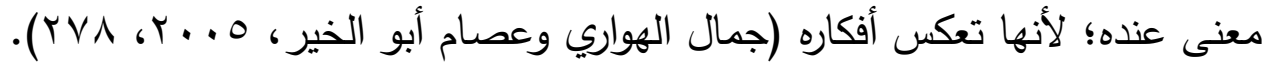
وفي ضـوء مـا سبق يتضـح أن مدخل الخبـرة اللغويـة يعتمد بشكل أساسـي على خبـرات المتعلمين ولغتهم الثخصـية؛ لينمـي المهارات المختلفـة لفنون اللغـة الأربعـة، و مهارات الابتكـار والإبداع لدى المتعلمين؛ لذا يجب على المعلم تتويع الأنشطة؛ لتتاسب خبرات التلاميذ واهتماماتم.

\section{ثالثًا : أهمية مدخل الخبرة اللفوية :}

يطلق على مدخل الخبرة اللغوية Language Experience Approach اسم المدخل الثامل Global Approach، حيث يتم فيه التكامل بين المهارات اللغوية الأربعة ( الاستماع . التحدث ـ القراءة ـ الكتابة )؛ وذلك لإحداث التتمية اللغويـة بين المتعلمين، ويعتمد على خبرات المتعلمين الشخصية التي اكتسبوها في حياتهم اليومية، ومن سنوات دراستهم السابقة، وعلى حصيلتهم اللغوية التي يسمعونها ويتحدثون بها. وهذا المدخل يستمد أنشطته داخل الصف الدراسي أو خارجه من خلال الرحلات الميدانية، أو أثياء حيوية عالقة بذاكرة التلاميذ في حياتهم الخاصة، ويجري المعلم مناقثات مـع التلاميذ حول

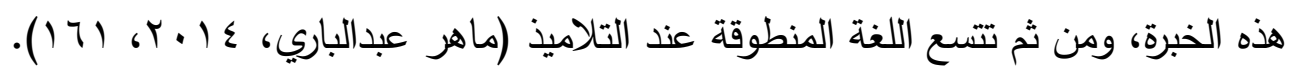
وتكمن الأهمية العظمى لمدخل الخبرة اللغوية في استخدامه مفردات التلاميذ الخاصـة، والنماذج اللغويـة المعتادة لديهج، وخبراتهم الثخصية في إنشاء مواد القراءة؛ وهذا من شأنه أن 
يجعل عملية القراءة هادفة وذات معنى وممتعة بالنسبة لهم؛ مما يساعدهم على فهم المعنى، واستيعاب الأفكار، وامتلاك مهارات اللغة المتتوعة (1, 2008, Nessel \& Dixo). ومدخل الخبرة اللغويـة طريقة للتعلم والتدريس ابتكاريًا؛ حيث إن التفكير الابتكاري جزء أساسي وجوهري في هذا المدخل؛ فاستجابات التلاميذ لمثيرات الخبرة تكون متثعبة ومثيرة؛ مما يساعد على خلق وابتكار مواد القراءة، ويتحدد دور التلميذ في هذا المدخل كمنتج ومبتكر لهذه المواد اللغوية، أما دور المعلم فيتحدد في خلق بيئة تحررية، تشجع التلاميذ على الابتكار، وتخلق فرصًا مناسبة ومتكررة لهم؛ ليعبروا عن أفكارهم، وأن يستئير قدرات التلاميذ الابتكارية، ويقدم

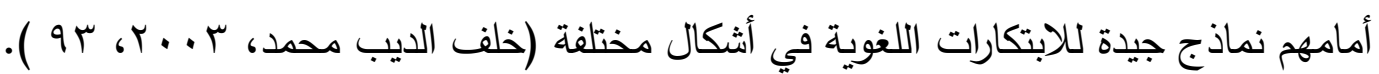
ومدخل الخبرة اللغوية طريقة هادفة للتعلم والتدري، حيث يهدف هذا المدخل إلى تتمية مهارات الاتصال اللغوي من خلال محتوى ذي معنى وهادف بالنسبة للتلاميذ، كما يهدف إلى فلى تعلم مهارات القراءة والكتابة بثكل أساسي (6-4, 1979, Hell)

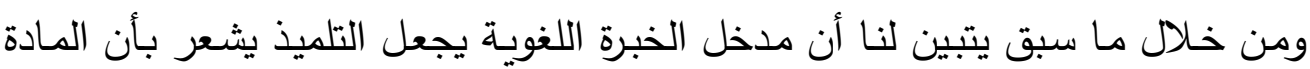

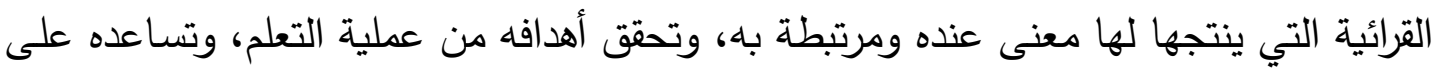
الابتكار والإبداع؛ فيقبل عليها ويفهم معناها ويتعلم من خلالها مهارات اللغة المختلفة، حيث إن مـا يقرأه وما يكتبه يتحدث بهه، وما يكتبه زملاؤه يمكنه قراءته؛ وهذا يخلق لديه دافعية جيدة للتعلم، وينمي المهارات اللغوية المتتوعة لديه. ومن هنا يتضح أن مدخل الخبرة اللغوية يساعد على فهم التلاميذ للمجتمع الذي يعيشون فيه، وطبيعة العلاقات التي توجد بين أفراده، وينمي لديهم روح التعاون، ويعزز مهارات الاتصال الفعال لليهم، ويمكن أن يضيف الباحث بعض الفوائد الأخرى لمدخل الخبرة اللغوية، وهي: ينمي مهارات الإبداع لاى التلاميذ، ويخلق لديهم شعور إيجابي نحو مهارات اللغة.

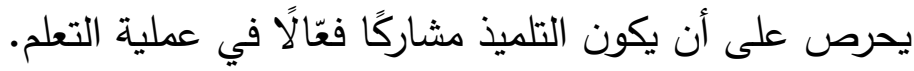
يعوّد التلاميذ التعبير عن خبراتهم الثخصية بلغتهم المألوفة. يوسع دائرة المفردات اللغوية لدى التلاميذ. يساعد التلاميذ على الطلاقة في القراءة؛ لأنهم يتعاملون مع مفردات مألوفة من واقع لعردي

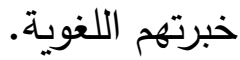


وفي ضسو أهميـة مـخل الخبرة اللغويسة يمكن استنباط بعض الأسس التـي يجب مراعاتها عند بناء برنامج الاراسة وتدريسه، وهي:

• إتاحة الفرصة للتلاميذ لمقارنة اكتثافاتهم بما هو مكتوب في النصوص القرائية.

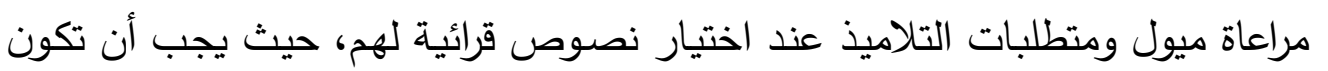
هذه النصوص ذات صلة مباشرة بواقعهم وحياتهم الشخصية. تتمية روح التعاون المثمر أثناء التعلم من خلال تقديم أنثطة تعاونية، وتقسيم التلاميذ

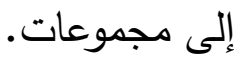
تشجيع مشاركة أفكار التلاميذ الختلفة وتداولها بينهز؛ للعمل على تكامل الخبرات وتتوعها.

رابعًا : خطوات مدخل الخبرة اللفوية وإجراءته التلدريسية لتنمية مهارات السرعة القرائية. تتـاول كثير مـن الباحثين مدخل الخبرة اللغويـة بالدراسـة، وحددوا إجراءاتـه وخطواتـه والتطبيقات التي يتعين القيام بها عند استخدامه في التعليم والتتريس، وإن جاءت هذه الخطوات

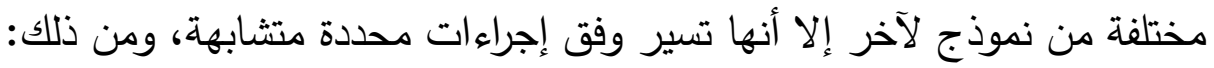
قد أثارت دبرا بورجيس ( Burgess,2003,2) إلى خطوات عامة لجميع أشكال مدخل

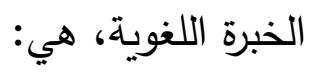
أ) المناقثة: والهدف من هذه الخطوة إرساء الموضوعات، أو المفاهيم، والخلفية المعرفية

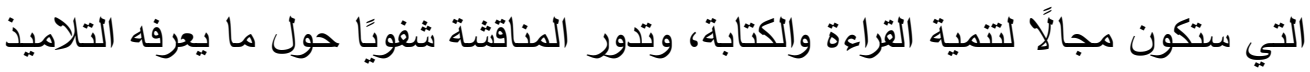
عن موضوع معين، مثل: الرحلات أو الأحداث الجارية.

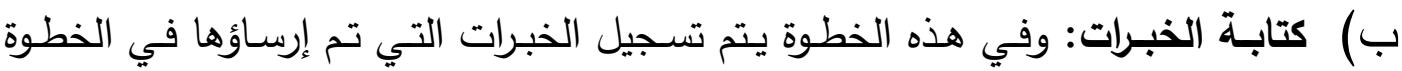

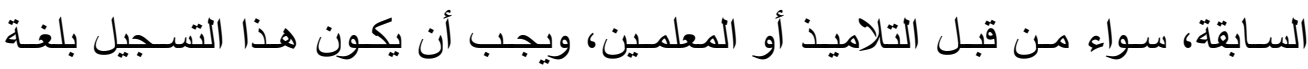
التلاميذ، بعيدًا عن التحيز للغة الأصلية.

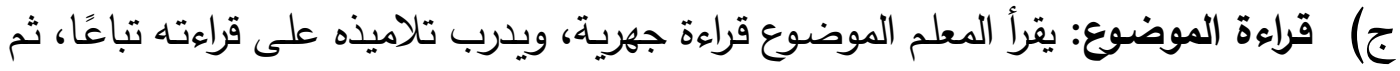

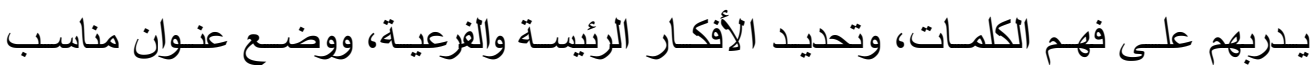
للموضوع. د) التحليـل والمتابعـة: وفي هذه الخطوة يـتم تحليل الكلمـات والجمل ذات الدلالــة في موضوع الدرس، وتدريب التلاميذ على فهمها، وإجادة استعمال الكلمات ومن ثَّمّ تحرير

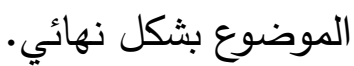


- دراسة جمال حسن ( Gamal,2005) التي أوضحت أن خطوات التدريس القائم على الخبرة

$$
\text { اللغوية تتمثل في الإجراءات الآتية: }
$$

أ) إتاحة الفرصة للتلاميذ ؛كي يعبروا عن خبرتهم.

ب) يكتب المعلم على السبورة المفردات وتراكيب الجمل التي ذكرها التلاميذ.

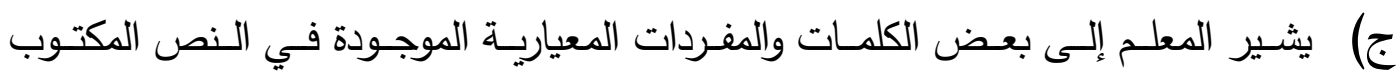

$$
\text { على السبورة. }
$$

د) مناقشة التلاميذ في هذه الكلمات.

هـ) استخدام كروت الإثارة ولصقها على الكلمات المكتوبة في النص. ( كروت الإثارة عبارة

عن كروت تتضمن مجموعة من الأسئلة والاستفسارات تتعلق بالمفردات المكتوبة).

و) يكتب التلاميذ النص في كراساتهم الخاصة؛ مما يساعد على ألفة التلاميذ للمفردات

$$
\text { اللغوية الموجودة في النص. }
$$

ز) قراءة التلاميذ للنص قراءة جهرية صحيحة.

ح) تقويم المعلم المستمر لكتابات التلاميذ وقراءتهم.

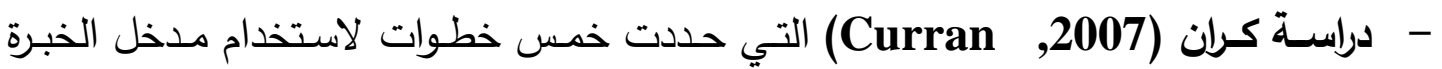

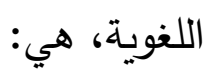

1- تزويــ الدارسين وإمـدادهم بخبرة ذات معنى بالنسـبة لهم مثل: رحلـة، أو صـورة، أو

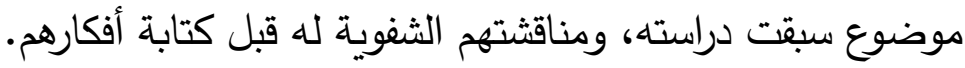

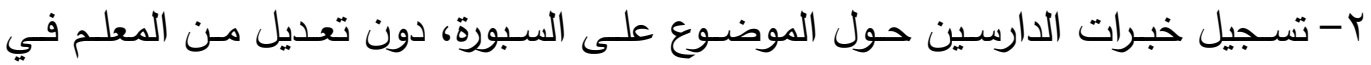

تعبيراتهم الخاصة.

ب- قراءة النص الجماعي الذي أنثأه الدارسون قراءة جهرية معبرة.

ع - ممارسة مجموعة من الأنثطة التي تعزز تعرف الدارسين الكلمات الجديدة.

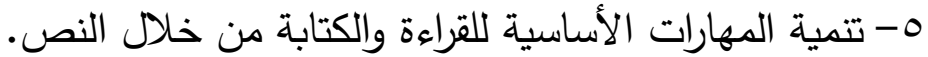

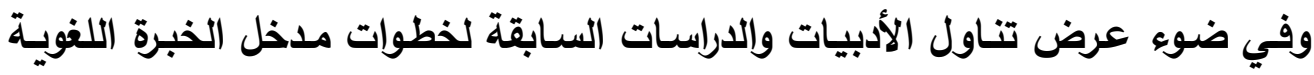
يتبين ما يأتي:

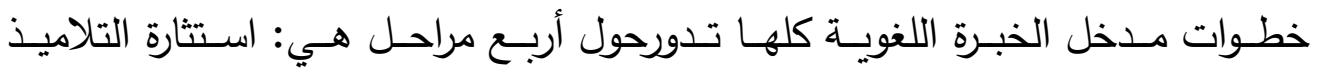
ومناقشتهم حول الخبرات المرتبطة بموضوع ما، وكتابة استجاباتهم حول الخبرة المقدمة، 
وقراءتهم لما كتبوه قراءة صحيحة، ثم تدربهم على مهارات لغوية محددة من خلال نص . الخبرة الذي أمامهم.

بعض الدراسـات أكدت أن يكتب التلميذ بنفسـه أو مـع المعلم النص القرائي بناءً على خبرته ومعرفته السابقة، والبعض الآخر يرى اختيار النصوص القرائية في ضوء خبرة التلاميذ اللغويـة؛ لتكون هذه النصوص ثريّة ومتتوعة، ويستطيع المعلم تدريب التلاميذ على المهارات اللغويـة من خلالها، والباحث يميل إلى الرأي الثاني، حيث إن مهارات السرعة القرائية متتوعة وكثيرة وتحتاج إلى نصوص معدة جيدًا في ضوء خبرة التلاميذ؛

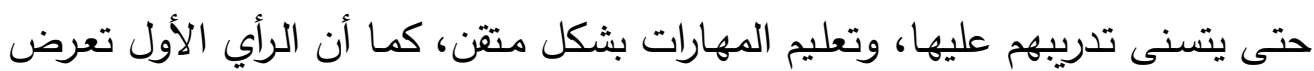
لكثيرمن الانتقادات منها (Dorr,2006,140 ) و(Burgess, 2003,2): إن المواد التعليمية الخاصـة التي يمكن استخدامها وفق هذا الرأي محدودة؛ مما يحول دون تتابع المهارات وتتميتها. يفتقر مدخل الخبرة في هذه الحال إلى تنمية المهارات المتسلسلة، مع عدم وجود تكرار نظامي للكلمات والجمل. قد لا تتمتع المواد التي أنتجها التلاميذ بجودة أدبية عالية. وفي ضوء خطوات مدخل الخبرة اللغوية ومراعاة طبيعة الدراسة الحالية، يمكن للباحث أن يحدد خطوات وإجراءات استخدام مدخل الخبرة اللغوية في تتمية مهارات السرعة القرائية لدى تلاميذ الصف الخامس الابتدائي فيما يأتي: يحدد المعلم موضوعًا قرائيًا في ضوء خبرة التلاميذ، ويكون من اختيارهم ويقع ضمن دائرة اهتمامهم، ويشبع ميولهم واتجاهاتهم، ثم يدرسه وفق المراحل الآتية: ا - مرحلة المناقثة: يناقش المعلم التلاميذ في الموضوع القرائي المحدد قبل القراءة؛ لاستثارة تفكيرهم، والتعرف على مـا لديهم من خبرات لغويـة ومعارف سابقة حول الموضوع، وذلك باستخدام إستراتيجية الحوار والمناقشة. ץ- مرحلة القراءة: وفيها يتم قراءة النص بدقة ويعتمد المعلم في هذه المرحلة على إستراتيجية القراءة المتكررة بممارساتها المختلفة فيقرأ المعلم النص القرائي قراءة نموذجية معبرة مراعيًا الدقة والأداء المعبر والسرعة ثم يطلب إلى التلاميذ قراءة النص قراءة متتالية، ويبدأ بالأمثل فالأقل؛ حتى يصل التلاميذ إلى المعدل المطلوب في القراءة. 
r- مرحلة التحليل الدلالي: وفيها يحلل المعلم و التلاميذ النص القرائي؛ للوقوف على الأفكار الرئيسة والأفكار الفرعية، معتمدين على إستراتيجية تحليل وفيل السمات الدالدالاتلية. ع- مرحلة الكتابة: وفيها يطلب المعلم إلى التلاميذ كتابة تعبيرات من إنشائهم تعبر عن مضمون التئن

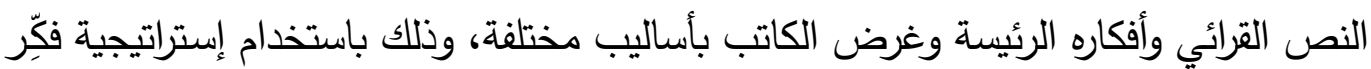
ناقش اكتب شارك، ثم تشارك كل مجموعات ما كتبته مع المجموعات الأخرى.

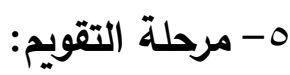

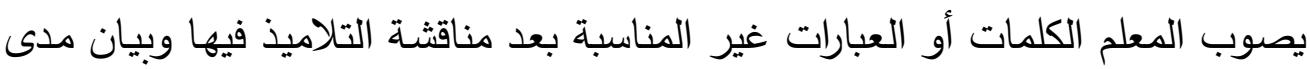

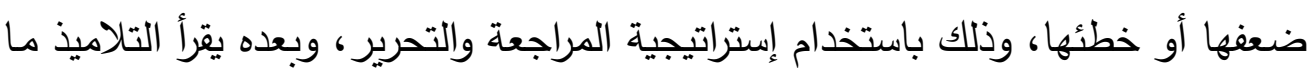

$$
\begin{aligned}
& \text { كتبوه مراعين السرعة. }
\end{aligned}
$$

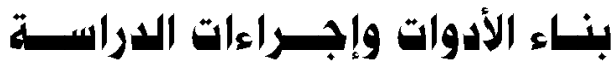

$$
\begin{aligned}
& \text { ا- قائمة مهارات السرعة القرائية المناسبة لتلاميذ المرحلة الابتدائية: }
\end{aligned}
$$

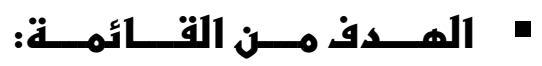

يتمثل هدف القائمة في: تحديد مهارات السرعة القرائية المناسبة لتلاميذ الصف الخامس

$$
\text { الابتدائي، واللازمة لهم في هذا الصف. }
$$

\section{• إعداد محتوى القائمة في صورته فئه الأولية:}

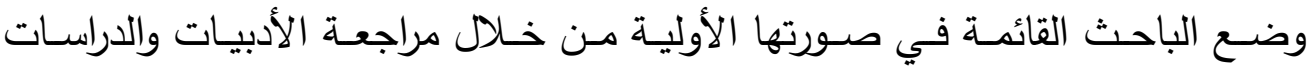

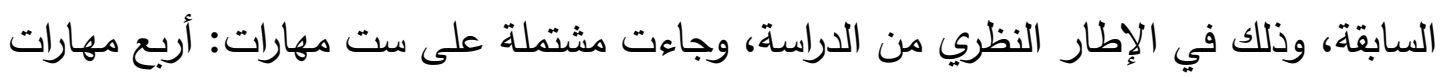

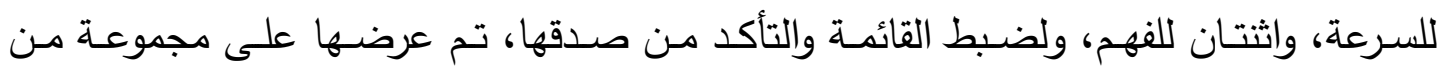

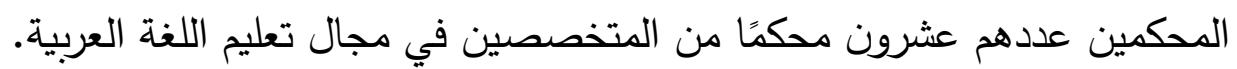

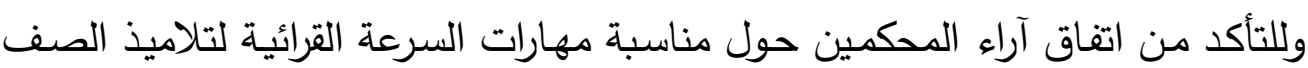

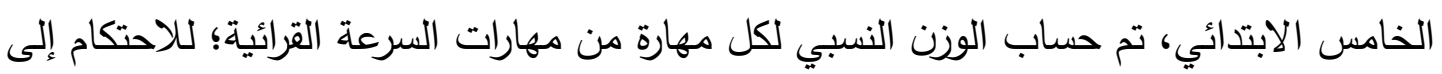

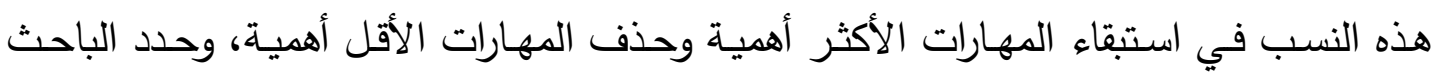

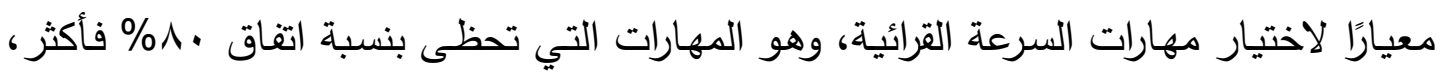
وتم حساب الوزن النسبي لكل مهارة بالمعادلة الآتية ('):

$$
(r \times r d)+(r \times, d)+(r \times, d)
$$

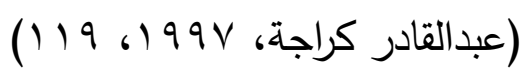

$$
\text { القيمة العظمى للوزت الثشبي }
$$

(1) (ك = = عدد المحكمين الذين اختاروا (مناسبة تماءًا). ، كى = عدد المحكمين الذين اختاروا (مناسبة). كى = عدد المحكمين الذين اختاروا (مناسبة إلى حد ما).، القيمة العظمى للوزن النسبي = (عدد المحكمين × ؟ $)$ 
• القائمة في صورنـها النهائبة: وبعد إجراء التعديلات التي اقترحها المحكمون، واستبعاد

المهارات التي لم يصل وزنها النسبي إلى ، ^\% أصبحت القائمسة تتضمن خمس مهارات

$$
\text { على النحو الآتي: }
$$

• يقرأ عددًا مناسبًا من الكلمات في الدقيقة الواحدة.

يغيّر نغمة القراءة فيما بين الشعر والنثر .

يقرأ الجمل في وحدات فكرية تامة مراعيًا مواضع الوقف والوصل.

يحدد الفكرة الرئيسة للمقروء.

$$
\text { يحدد الأفكار الفرعية في النص. }
$$

وبعد أن توصل الباحث إلى قائمة مهارات السرعة القرائية في شكلها النهائي، وأصبحت

تتمتع بالصدق العلمي، كان من الضروري بناء اختبار لقياس مستوى التلاميذ في هذه المهارات.

r- اختبارقياس السرعة القرائية :

• الههف من الاختبار: استهدف بناء اختبار مهارات السرعة القرائية قياس مستوى أداء تلاميذ

الصـف الخـامس الابتدائي لمهـارات السـرعة القرائيـة، وكذلك قيـاس مـدى النــو في تلكك المهارات بعد دراستهم موضوعات البرنامج القائم على مدخل الخبرة اللغوية. • وصف الاختبار: تكوّن الاختبار من قطعتين قرائيتين: الأولى نثريـة (القلوب الرحيمة) وعدد كلماتها مائة وثلاثون كلمة، والثانية شعرية (سليمان والطاووس) وعدد كلماتها سبع وتسعون كلمـة، وتمّ تقديم الاختبـار في نسختين: الأولى للمعلم، اسـتهلها الباحث بمقدمـة توضـح الهدف من الاختبار ، والتعليمات التي ينبغى الالتزام بها عند التطبيق، ثم عرض النصين موضحًا عدد كلمـات كل سطر، وبعدها قدّم مفردات الاختيار من متعدد لقياس مهارات الفهـ، وبيّين طريقـة تقيـيم مهـارات السـرعة، أمـا النسـخة الثانيـة فنسـخة التلميذ، قدّم فيهـا القطعتين كل واحدة في ورقة منفصلة تعقبها أسئلة الاختيار من متعدد لقياس الفهم. • ضبط الاختبار وبطاقة التقدير : قام الباحث بعرض الاختبار وبطاقة التقدير على مجموعة من المحكمين لإبداء الرأي فيهما، وقد أبدى المحكمون آراءهم على النحو الآتي: ضرورة ضبط بنية كلمات النصيين ضبطًا تامًا؛ ليستطيع التلميذ قراءاتها بشكل صحيح في أقل وقت ممكن ،وقد استجاب الباحث لذلك. 
مراعاة طول البدائل المقترحة في أسئلة الاختيار من متعدد؛ حتى لا يلجأ التلميذ إلى التخمين نتيجة قصر بعض العبارات أو طولها، وقد ساوى الباحث بين البدائل المتترحة في الاختبار .

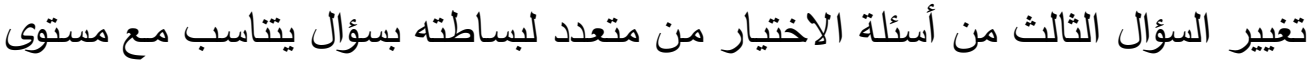

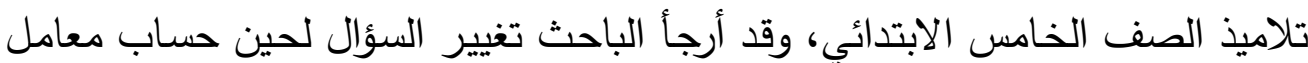
السهولة والصعوبة له.

إضافة بند جديد عند لحساب سرعة التلميذ في القراءة إذا أنهى قراءة النص قبل انتهاء

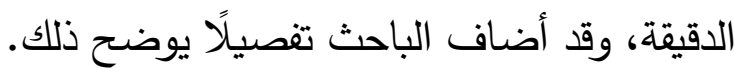

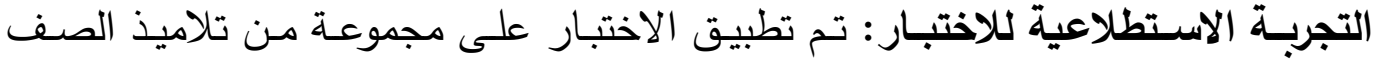

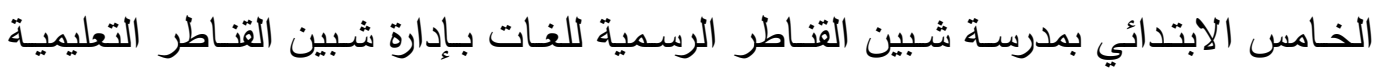

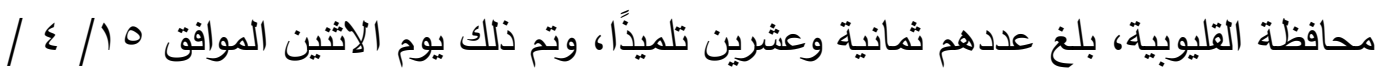
19 أr م، ثم استخدمت بينات هذا التطبيق في تحقيق الأهداف الآتية:

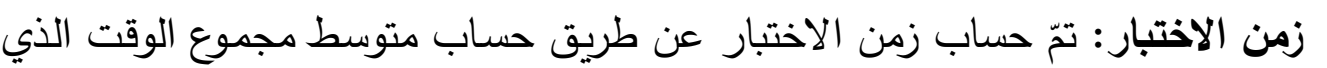

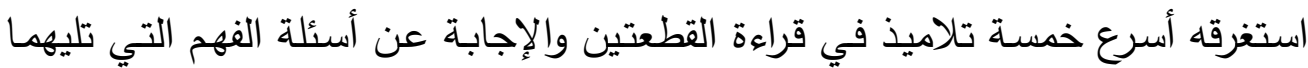
(مجموعة أولى)، ومتوسط مجموع الوقت الذي استغرقه أبطأ خمسة تلاميذ في قراءة القطعتين والإجابة عن الأسئلة التي تليهما ،فكان زمن الاختبار عشرين دقيقة تقريبًا. ب) ثبات الاختبار: وباستخدام برنامج (SPSS-14) وحساب الثبات الكلي لاختبار السرعة

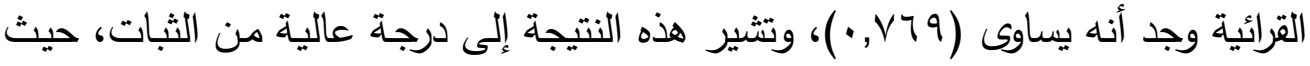

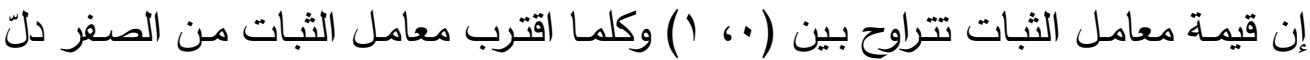
على عدم وجود ثبات، ومن هنا يتضح ثبات اختبار السرعة القرائية وصلاحيته للتطبيق.

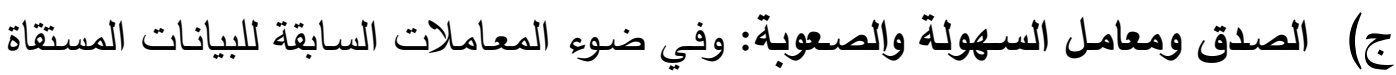

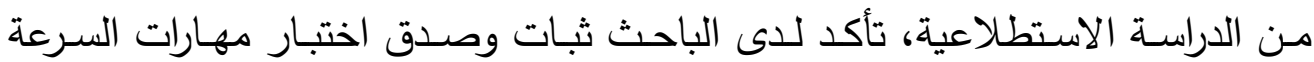

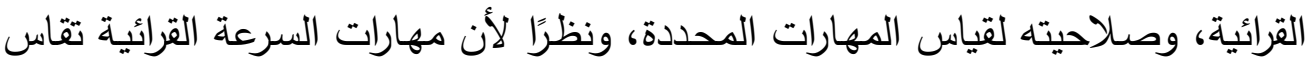
بطرق مختلفة، فمهارات السرعة تقاس ببطاقة تقدير ، أما مهارات الفهم فتقاس بمفردات التهات الاختيـار مـن متعدد، فإن حسـاب معامـل السـهولة والصـوية تم بطريقتين: معاملـل

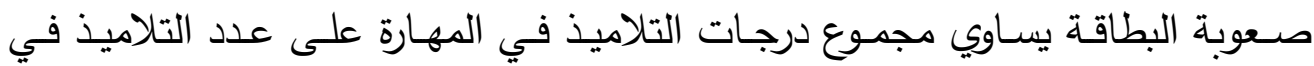

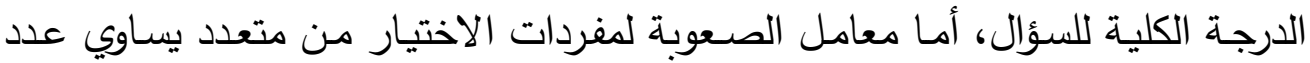
الإجابات الخطأ عن السؤال على عدد التلاميذ وبتطبيق ذلك تأكد الباحث من مناسبة أسئلة الاختبار لتلاميذ الصف الخامس الابتدائي. 


\section{ץ- برنامج تنمية مهارات السرعة القرائية باستخلام ملخل الخبرة اللفوية.}

\section{1 أ) الهـــف العــام للبــرنـامـهم.}

يستهدف برنامج الدراسة الحالية تتمية مهارات السرعة القرائية التي سبق تحديدها لدى

$$
\text { تلاميذ الصف الخامس الابتدائي. }
$$

نظرًا لأن البرنامج يستهدف تتمية مهارات السرعة القرائية لدى تلاميذ الصف الخامس

الابتدائي في ضوء مدخل الخبرة اللغويـة، كان من الضروري اختيار محتوى قرائي يتناسب مـع طبيعة تلاميذ الصف الخامس وخبرتهم اللغويـة من ناحية، ومهارات السرعة القرائية من ناحية أخرى؛ لذا قام الباحث بإعداد قائمـة بالموضـوعات القرائية المناسبة لتلاميذ الصـف الخـامس الابتدائي في ضوء خصائصهم وقدراتهم العقلية واللغويـة، ثم عرض القائمسة على ثلاثين تلميذًا من تلاميذ الصف الخامس الابتدائي بمدرسة شبين القناطر القديمة رقم ب التابعة لإدارة شبين

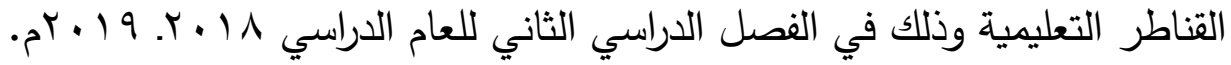
وبعد اختيـار التلاميذ للموضـوعات وإضـافة بعض الموضـوعات الأخـرى، قـام الباحث بإضافة الموضوعات التي اختارها التلاميذ وعرض القائمة على عشرة محكمين؛ للتأكد من مدى مناسبة هذه الموضوعات لتلاميذ الصف الخامس الابتدائي، وتم حساب نسبة اختيار الموضوعات وفق آراء التلاميذ وآراء السـادة المحكمين، ثم حسـاب المتوسط للنسبتين، وقد اعتمدت الدراسـة

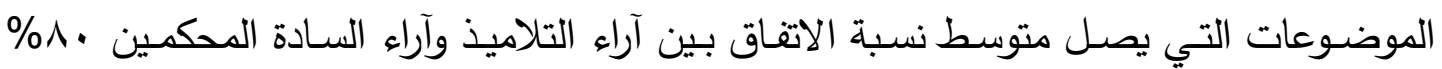

\begin{tabular}{|c|c|}
\hline r - فوائد الرياضة البدنية. & 1- حب الوطن (شعر أو نثر). \\
\hline ع - سير الخلفاء والأمراء. & r- اختراعات الصغار . \\
\hline 7- قصص للطير والحيوان. & ه- الثعر القصصي. \\
\hline \multirow[t]{2}{*}{ ^- احترام العمل وإتقانه. } & - V العناية بنظافة الجسم وصحته. \\
\hline & 9- قصص واقعية للكادحين أو المخترعين. \\
\hline
\end{tabular}
فأكثر ، وبهذا تكون قائمة موضوعات البرنامج في صورتها النهائية على الثكل الآتي:

وبنـاءً على هذه القائمـة النهائية، اختار الباحث تسعة موضـوعات؛ لتغطي المجالات التسعة الموجودة بالقائمة النهائية، ثم عمد إلى الربط بينهم، وتقديم الموضوعات بشكل متسلسل 
ومتفق مع طبيعة مهارات السرعة القرائية في صورة ثلاث وحدات دراسية؛ تماشيًا مـع صورة

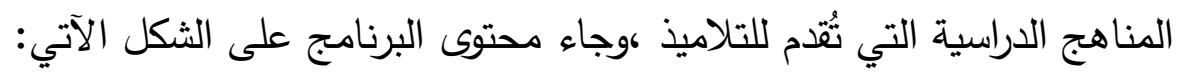
الوحدة الأولى (العمل من أجل الوطن) وتتضمن ثلاثة دروس، هي:

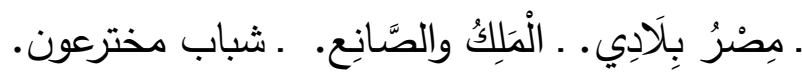

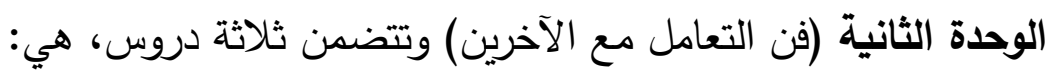

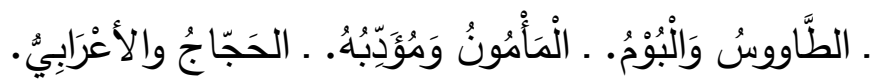
الوحدة الثالثة (قيم وسلوكيات) وتتضمن ثلاثة دروس، هي:

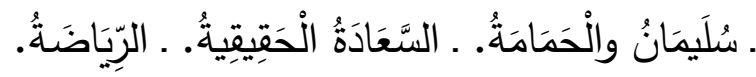

\section{ج) الوسائل التعليمية المطامبة للبرنامج.}

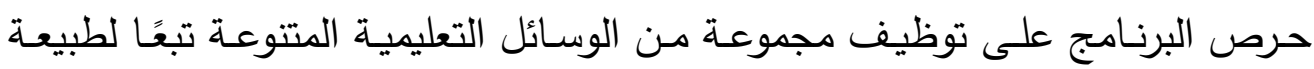
مهارات السرعة القرائية، والتي تساعد على تحقيق أهداف الدراسة الحالية، منها:

\begin{tabular}{|c|c|}
\hline • جهاز عرض البيانات. & جهاز حاسوب. \\
\hline • التسجيلات المرئية. & التسجيلات الصوتية. \\
\hline • العروض التقديمية. & البطاقات والصور • \\
\hline
\end{tabular}

د) الأنشطة التنعليمية المصاصبة البرنامج.

في ضوء طبيعة مهارات السرعة القرائية؛ فقد تضمن البرنامج مجموعة من الأنشطة اللغوية المتتوعة والثاملة، والتي يمكن أن تسهم في تحقيق أهداف البرنامج الحالي، منها:

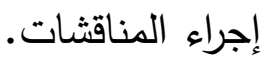
إشراك التلاميذ في مجموعات تعاونية لإنجاز بعض المهام. ت تدوين الملاحظات عند كل قراءة.

هكليف التلاميذ بالقراءة المتتالية للنص وتدوين سرعة القراءة في كل مرة. تكليف بعض التلاميذ الماهرين في القراءة بقراءة النص في الإذاعة المدرسية.

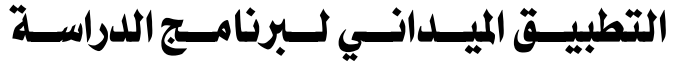

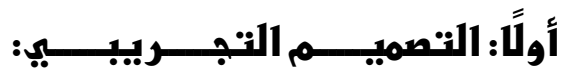

اعتمد الباحث في الدراسة الحالية على التصميم شبه التجريبي ذي المجموعة الواحدة ذات القياس القبلي والبعدي، وقد اختار الباحث هذا التصميم نظرًا لحداثة البرنامج، وعدم وجود لئهي 
مثل هذه الموضـوعات في منـاهج اللغـة العربيـة لتلاميذ الصف الخـامس الابتدائي، كمـا أن الطريقة التي تدرس بها التي تقوم على مدخل الخبرة اللغوية تختلف عن الطريقة العادية التي

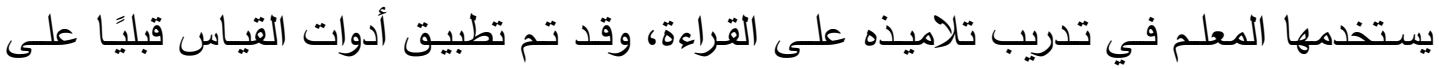
مجموعة الدراسـة ثم تدريس البرنامج القائم على مدخل الخبرة اللغويـة لهم، ثم تطبيق أدواتهات القياس على الدجموعة نفسها بعد تدريسهم البرنامج.

\section{ثنانيًا: تـــــيد مجمــو عة الــــراســـة:}

عند تحديد مجموعة الدراسة عمد الباحث إلى استبعاد التلاميذ الذين لديهم عيوب في

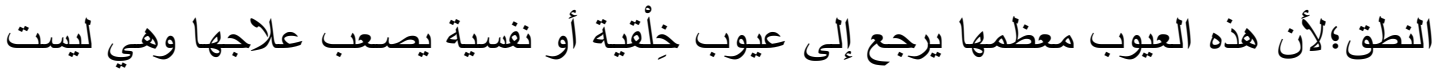
موضع اهتمام الدراسة الحالية، ومن ثََّ تؤثر بالسلب على نتائج الدراسة، وقد تمثلت هذه العيوب

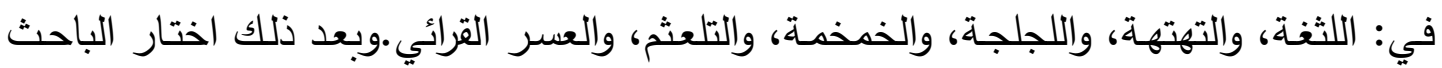
مجموعة من تلاميذ الصف الخامس الابتدائي المسجلين بمدرسة فجر الإسلام الخاصة بشبين

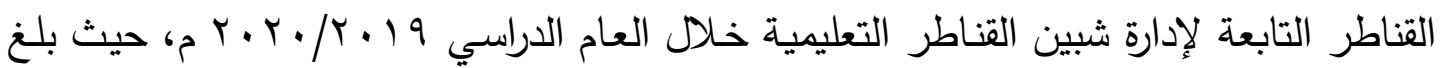
عددهم اثثين وثلاثين تلميذًا.

\section{ثالثًا: النطبيزة القبلي لافتنبار السر عة القرائية:}

تم التطبيق القبلي لاختبار مهارات السرعة القرائية في يومي الأحد والاثثين الموافقين

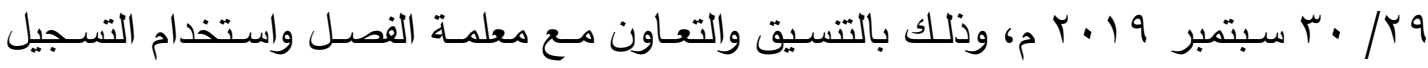
المرئي لكل تلميذ في أثناء القراءة.

\section{رابعًا: تدريسر البرنامج (التطبيةق الميداني):}

لقد آثر الباحث تطبيق البرنامج بنفسه؛ حرصًا على الدقة في التنفيذ، وانشغال معلمي التهي

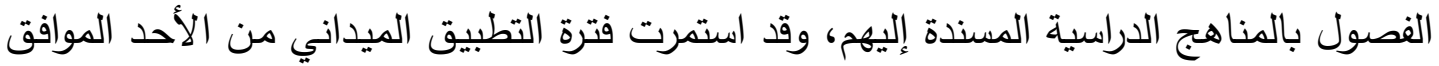

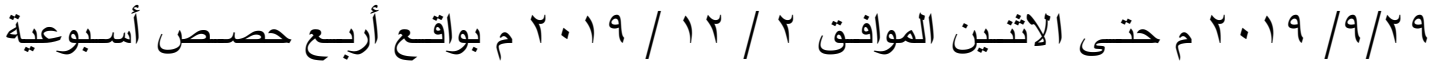
موزعة على يومين لكل درس من دروس البرنامج. بعد الانتهاء من تدريس البرنامج الذي استغرق تسعة أسابيع، تم إجراء التراء التطبيق البعدي

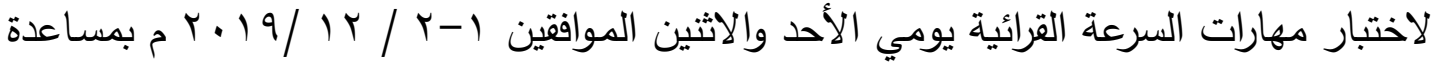

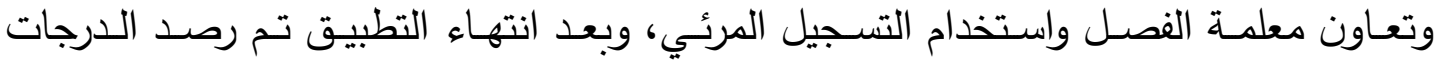

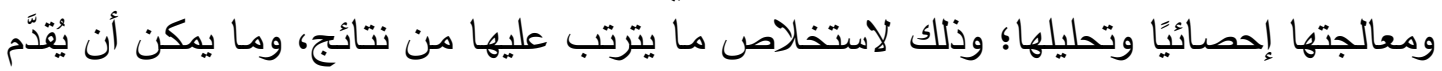

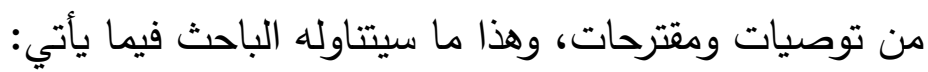




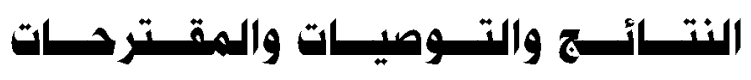

أولا ؛ بيان نتائج مهارات السرعة القرائية :

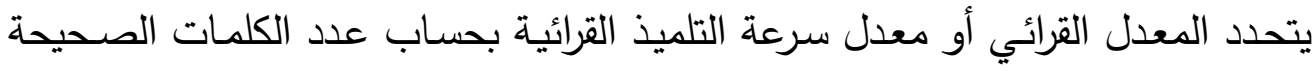

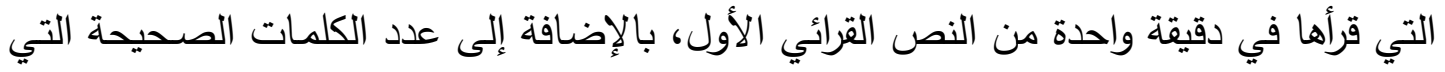

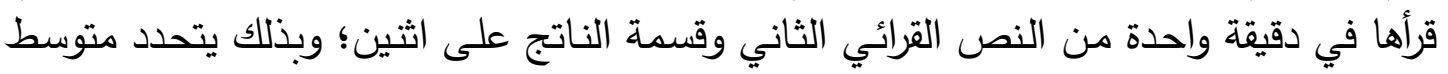

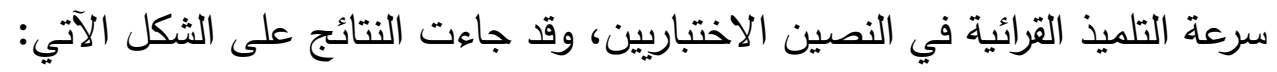

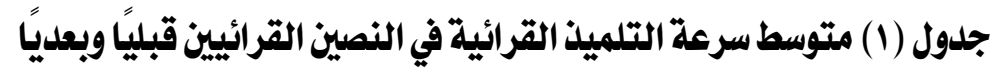

\begin{tabular}{|c|c|c|}
\hline متوسط السرعة القرائية للنصين بعديا & متوسط السرعة القرائية للنصين قبليا & مسـلسـل التلمـيذ \\
\hline 9. & 7. & 1 \\
\hline 1111 & $1 \cdot r \square$ & $r$ \\
\hline 117 & VI & $r$ \\
\hline $9 \xi$ & Ar & $\xi$ \\
\hline 111 & Av & 0 \\
\hline $7 r$ & 0. & 7 \\
\hline $1+r$ & 11. & $\checkmark$ \\
\hline $1 \cdot 1$ & 97 & $\Lambda$ \\
\hline AI & vq & 9 \\
\hline 97 & 7. & 1. \\
\hline 1.1 & 99 & 11 \\
\hline 1.7 & 97 & Ir \\
\hline 1.1 & Aร & ir \\
\hline IrY & 114 & 18 \\
\hline 1.0 & 11. & 10 \\
\hline$|M|$ & 98 & 17 \\
\hline 1.0 & 90 & iv \\
\hline 7. & rr & 11 \\
\hline 110 & VY & 19 \\
\hline$\$ 1$ & 17 & r. \\
\hline 1.7 & 94 & YI \\
\hline $1 \leqslant 7$ & 11. & rr \\
\hline $1 \cdot 1$ & 98 & rr \\
\hline 94 & IV & Y६ \\
\hline 11. & A. & ro \\
\hline $1 \leqslant 0$ & 100 & ry \\
\hline $9 r$ & AY & PV \\
\hline IrA & 94 & rA \\
\hline $1 \cdot Y \square$ & 91 & $r q$ \\
\hline VV & 89 & $r \cdot$ \\
\hline Ar & 07 & m \\
\hline or & $\$ 0$ & $r r$ \\
\hline $99, V$ & $\Lambda \cdot, r \square$ & متوسط السرعة للتلاميذ \\
\hline
\end{tabular}




$$
\text { وباستقراء الجدول السابق يتضح أن: }
$$

هعدل سرعة القراءة لتلاميذ الصف الخامس الابتدائي قد ارتفع بشكل ملحوظ، حيث بلغ

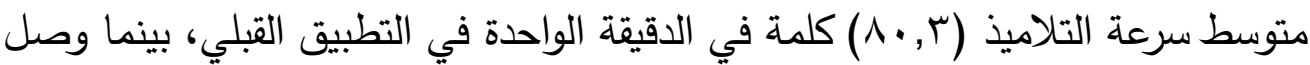

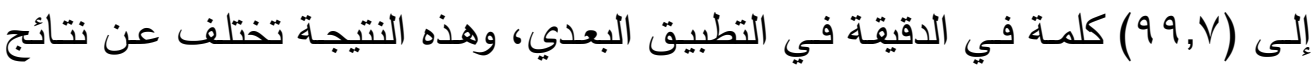

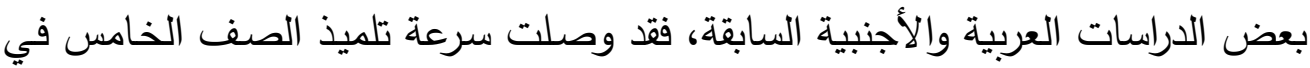

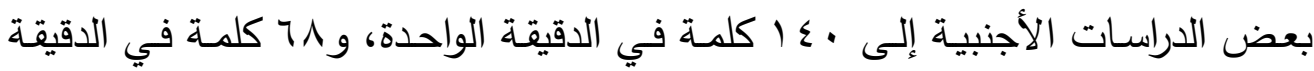

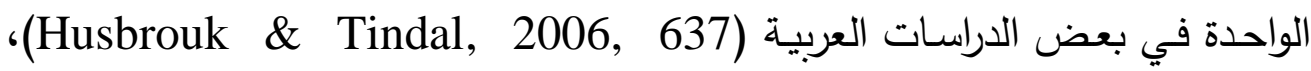

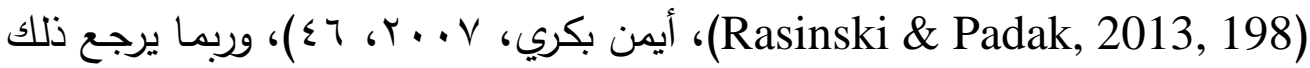

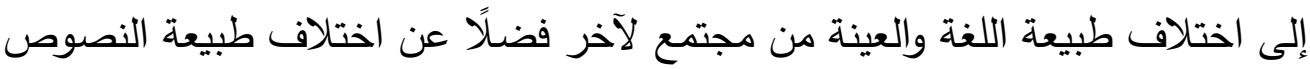

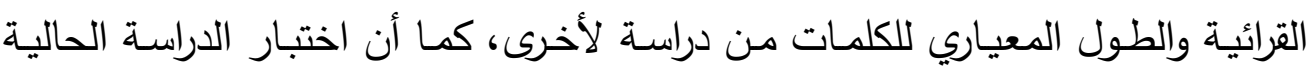

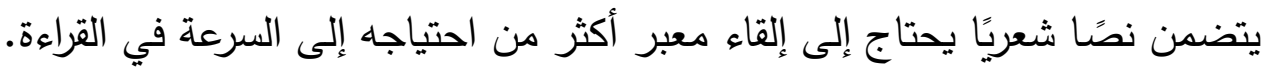

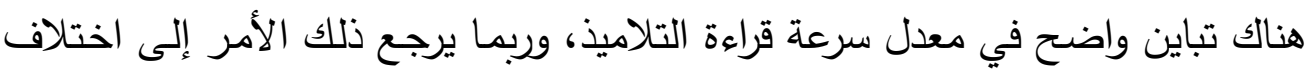

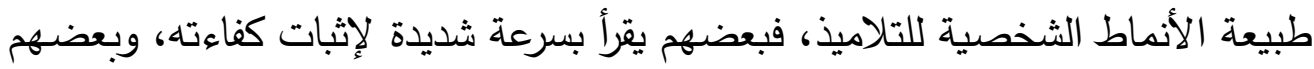

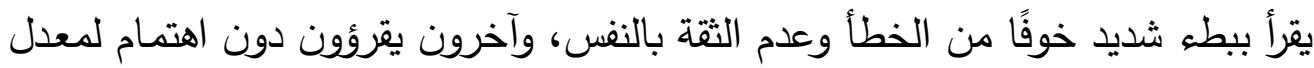

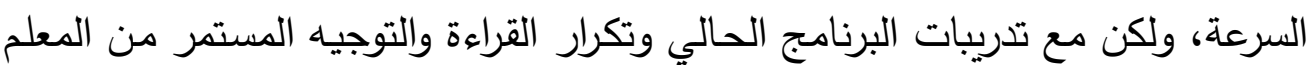

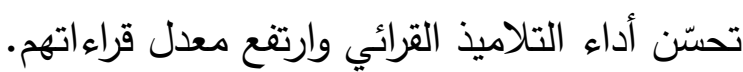

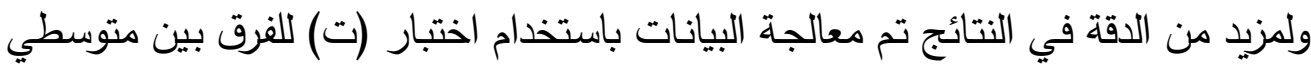

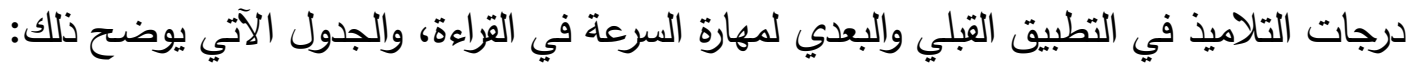

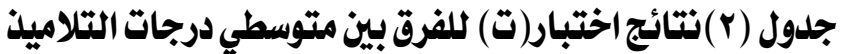
في التطبيق القبلي والبعدي المهارات السرعة القرائية التئية

\begin{tabular}{|c|c|c|c|c|c|c|c|}
\hline حجم التأثيّير & مستوى اللالة & قيمة & الحرية درجة & الانمياري & المتوسط & التطبيق & المهــــــــــارة \\
\hline \multirow{2}{*}{$\cdot, \wedge \cdot$} & \multirow{2}{*}{$\cdot, \cdot 1$} & \multirow{2}{*}{$11, \cdot \bullet$} & \multirow{2}{*}{ rl } & $\xi,\{\xi$ & 19,70 & البعلدي & \multirow{2}{*}{ مجموع مهارات السرعة القرائية } \\
\hline & & & & I,Ar & 11,10 & القبلي & \\
\hline \multirow{2}{*}{$\cdot, V r$} & \multirow{2}{*}{$\cdot, \cdot 1$} & \multirow{2}{*}{9,17} & \multirow{2}{*}{ ri } & $1, r r$ & $0, \cdot r$ & البعلي & \multirow{2}{*}{ • ت يقـرأ عـلدة مناسـبـا مـن الكلمـات في } \\
\hline & & & & 1,17 & $r, 10$ & القبلي & \\
\hline \multirow{2}{*}{$\cdot, \mathrm{VV}$} & \multirow{2}{*}{$\cdot, \cdot 1$} & \multirow{2}{*}{$1 \cdot, Y \varepsilon$} & \multirow{2}{*}{ rI } & 1,18 & $\xi, r \wedge$ & البعلدي & \multirow{2}{*}{ • يفير نفمة القراءة فيمها بـين الشعر } \\
\hline & & & & $\cdot, 0$ & r,Yo & القبلي & \\
\hline \multirow{2}{*}{$\cdot, \mathrm{V}$} & \multirow{2}{*}{$\cdot, \cdot 1$} & \multirow{2}{*}{$9, \leqslant 7$} & \multirow{2}{*}{ m } & 1,17 & $\xi, 07$ & البعلدي & \multirow{2}{*}{ 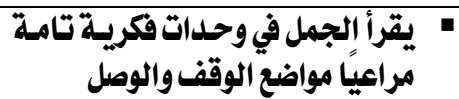 } \\
\hline & & & & $\cdot$, Yo & $r, 09$ & القبلي & \\
\hline \multirow{2}{*}{$\bullet, Y 7$} & \multirow{2}{*}{$\cdot, \cdot 0$} & \multirow{2}{*}{ r, r } & \multirow{2}{*}{ r } & I,AY & $\boldsymbol{\varepsilon}, \Lambda V$ & البعلدي & \multirow{2}{*}{ • يحلد الفكرة الرئيسة للمقروي } \\
\hline & & & & $1,9 v$ & $r, 70$ & القبلي & \\
\hline \multirow{2}{*}{$\cdot, 01$} & \multirow{2}{*}{$\cdot, \cdot 1$} & \multirow{2}{*}{$0, v \varepsilon$} & \multirow{2}{*}{ M } & $r, \cdot \cdot$ & $\xi, 71$ & البعلي & \multirow{2}{*}{ • يحلد الأفكار الفرعية في النص } \\
\hline & & & & $r, 1 \cdot$ & 1,97 & القبلي & \\
\hline
\end{tabular}




$$
\text { وباستقراء الجدول السابق يتضح: }
$$

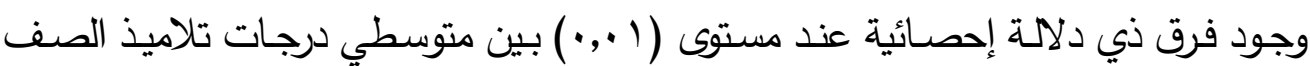

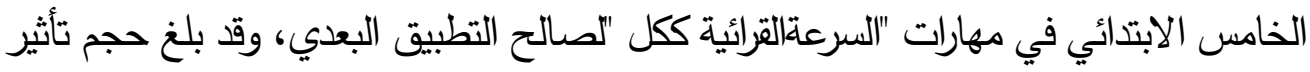
البرنامج (•^^,·)، وهو حجم تأثير مرتفع، يشير إلى ارتفاع مستوى مهارات السرعة القرائية لديهم؛ مما يدل على فاعلية البرنامج القائم على مدخل الخبرة اللغوية في تتمية هذه المهارات،

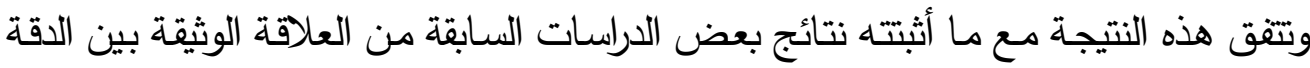

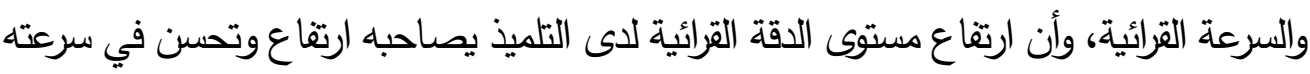

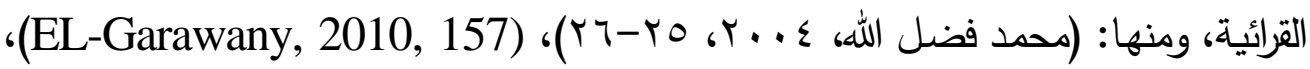

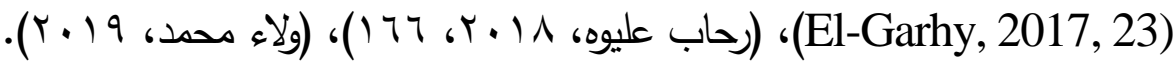

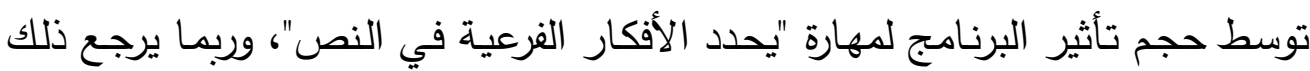

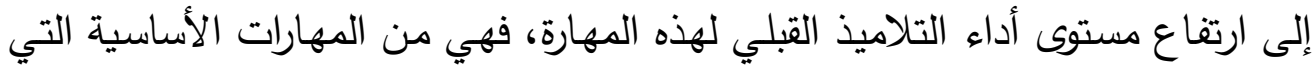

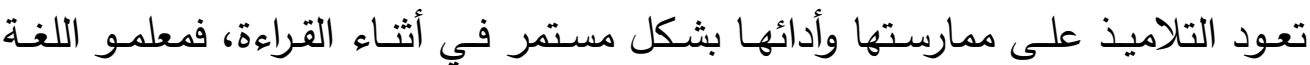
العربية يركزون في تدريسم للقراءة على معرفة دلالة الكلمات وتحديد الأفكار الفرعية للمقروء أكثر من المهارات الأخرى للقراءة؛ مما انعكس على أداء التلاميذ لهذه المهارة.

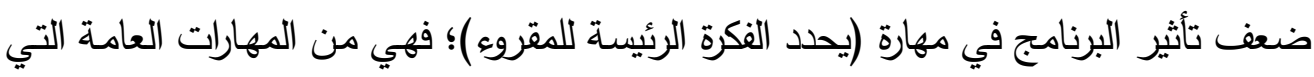

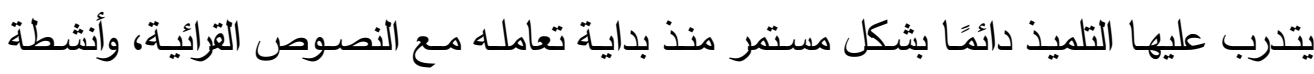
الكتاب المدرسي تركز عليها؛ وهذا ساعد التلاميذ على أدائها بثكل جيد من البداية. ويمكن تفسير النتيجة السابقة بأن التحسن في السرعة القرائية يرجع إلى:

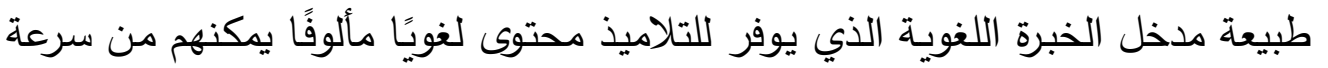

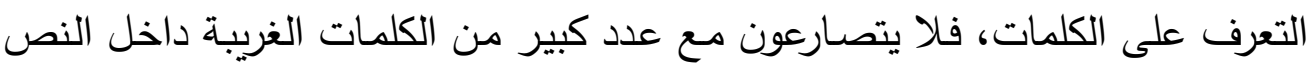

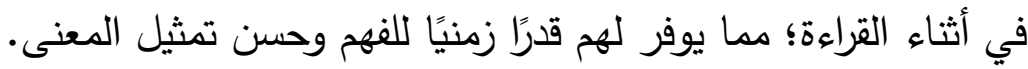
ه اعتماد مدخل الخبرة اللغوية على إستراتيجيات متتوعة، تقوم كل إستراتيجية بدور مناسب في عملية التعلم، فإستراتيجية المناقثة والحوار تقرب لغة النص الترائي إلى التلاميذ وتجعل محتواه مألوفًا بالنسبة لهم، وتحليل السمات الدلالية للنص الدقروء تساعدهم على تحديد أفكاره الرئيسـة والفرعيـة، وتجعل نظرتهم للنص تتسم بـالعمق، كمـا أن القـراءة المتكررة تساعدهم على سرعة القراءة وتجعلهم يركزون على عملية الفهم ودقة الأداء القرائي. 
هاختيار نصوص قرائية مألوفة بالنسبة للتلاميذ ،وتقع في حدود خبرتهم ومناسبة لميولهم،

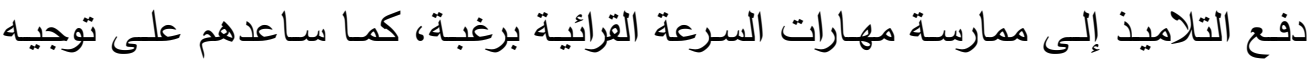
جهودهم نحو تثفير الكلمات بدقة وسرعة.

تكرار قراءة التلميذ للكلمات والجمل، وحساب المعدل القرائي في كل قراءة، أشعل روح المنافسة بين التلاميذ، كما أن تعاون التلاميذ في عد الكلمات وطرح الأخطاء والإعلان

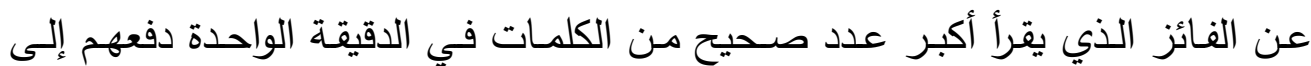
تحسين معدل سرعتهم القرائية. الاهتمام بتكرار التدريب على رفع معدل السرعة القرائية، وتسجيل السرعة ومعدل النمو في بطاقة التلميذ الموجودة بكتيب التلميذ، ساعد التلاميذ على تتبع نمو وتطور سرعتهم القرائية ودفعهم إلى تكرار القراءة وصولًا لأقصى سرعة ممكنة في الدقيقة الواحدة. وفي ضـوء مسا سـبق يمكن القول بأنسه: يوجد فرق ذو دلالتة إحصـائية عند مستوى ( ( . • ) بين متوسطي درجات تلاميذ الصف الخامس الابتدائي في مهارات السرعة القرائية ككل بهل وفي كل مهارة على حدة لاختبار مهارات الطلاقة القرائية قبليًا وبعديًّا لصالح التطبيق البعدي.

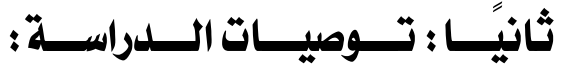

ه اختيار نصوص قرائية متتوعة من واقع خبرة التلاميذ الثخصية؛ لتساعدهم على التقدم في القراءة وتوفر لديهم وقتًا أكبر للفهم والأداء المعبر • بناء الدروس والموضوعات القرائية وفق مراحل وإجراءات مدخل الخبرة اللغويـة؛ لتقريب لغة النص القرائي للتلاميذ ومساعدتهم على فهم محتواه بصورة متسلسلة. تضمين مهارات السرعة القرائية في مناهج اللغة العربية بالتعليم الأساسي بشكل واضـح يتيح للتلاميذ التدريب عليها بصورة مستمرة.

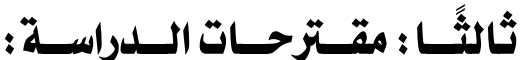

استخدام مدخل الخبرة اللغوية في تتمية مهارات الاستماع لدى تلاميذ المرحلة الابتدائية. برنامج قائم على مدخل الخبرة اللغوية في تتمية مهارات الكتابة الهجائية لدى التلاميذ ذوي القدرات الخاصة القابلين للتعلم. تحديد معدلات السـرعة القرائيـة تبعـا للنصـوص القرائيـة المختلفة(شـعر، مقـال، قرآن، قصة، خطبة). فاعلية القراءة القصصية في تتمية مهارات السرعة القرائية لدى التلاميذ ذوي صعوبات التعلم. 

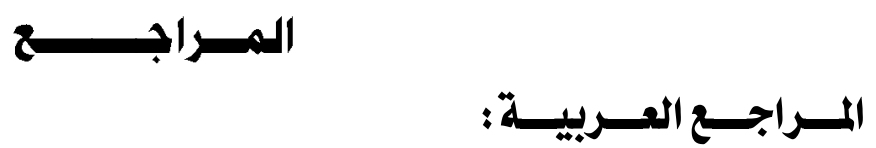

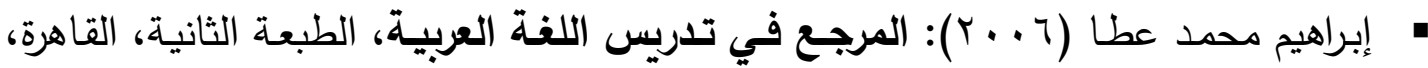

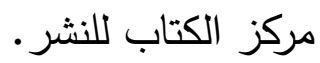

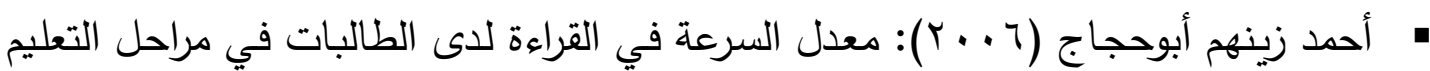

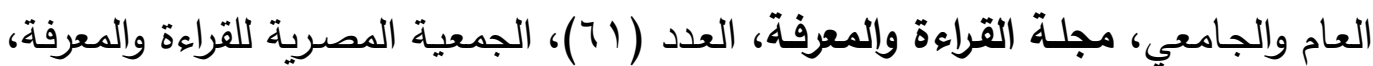

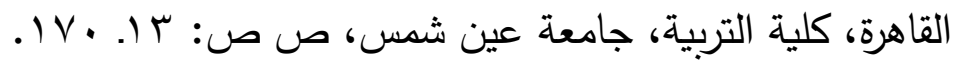

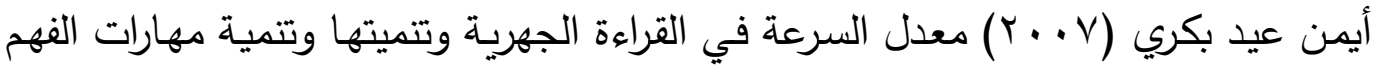

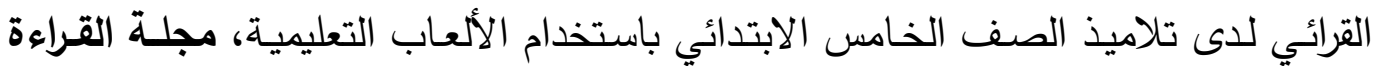

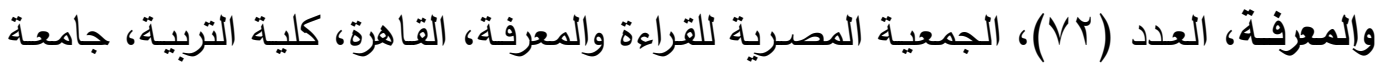

$$
\text { عين شمس، ص ص ص با I. } 71 .
$$

أيمن خليل ( • • ( ) ): الأسس التي تقوم عليها الاتجاهـات المعاصـرة في إعداد بـرامج

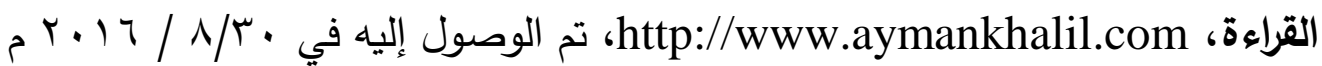
جمال فرغل الهواري؛ عصام محمد أبو الخير (0 . . †): أثر التفاعل بين التدريس باستخدام نمطي مدخل الخبرة اللغوية (فردية - جماعية) والأسلوب المعرفي (المخاطرة - الحذر) في تتمية بعض مهارات الإبداع اللغوي لدى عينة من تلاميذ الصف الثاني الإعدادي الأزهري،

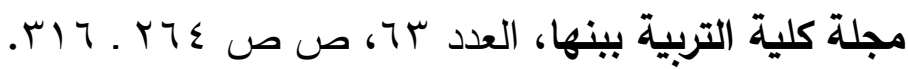

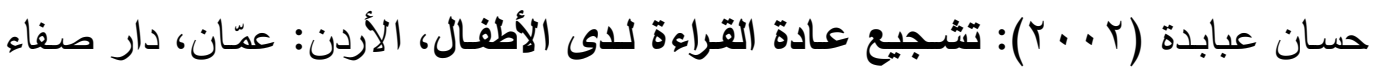
للنشر والتوزيع. حسن سيد شحاتة (T 1 • ץ): المرجع في فنون القراءة العربية لتثكيل إنسان عربي جديد، القاهرة، دار العالم العربي.

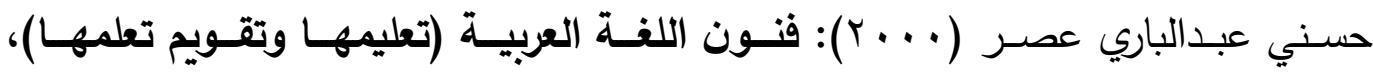
الإسكندرية، مركز الإسكندرية للكتاب. " مدان علي نصر (999 (19): معدل السرعة في القراءة الصـامتة لدى تلاميذ نهاية الحلقة

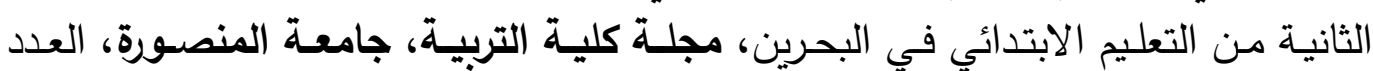

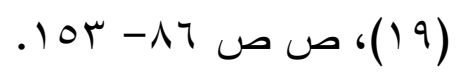

خالد حماد شارع اللهو (7 ( r): أثر برنامج قائم على الأسئلة السقراطية وإستراتيجيات ما وراء المعرفة في تحسين الطلاقة والفهم القرائي وفق أنماط التعلم المخي لذوي صعوبات التعلم مسن تلاميذ المرحلـة المتوسبطة بدولـة الكوبــ، رسـالة دكتوراه غير منشورة، كليـة الدراسات العليا للتربية، جامعة القاهرة. 


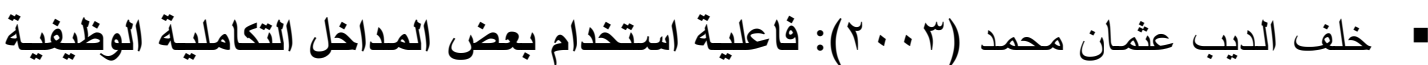

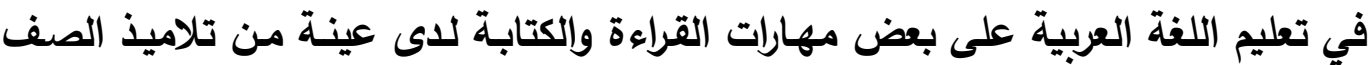
الرابع الابتدائي، رسالة دكتوراه غير منشورة، كلية التربية، جامعة الأزهر .

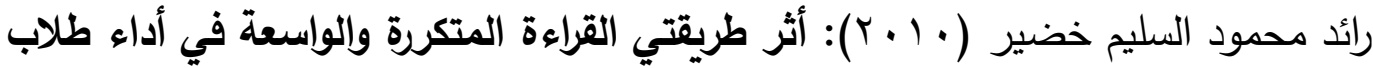

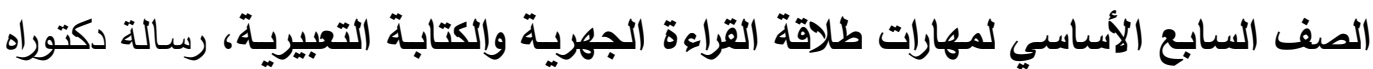
غير منشورة، كلية التربية، جامعة اليرموك، الأردن.

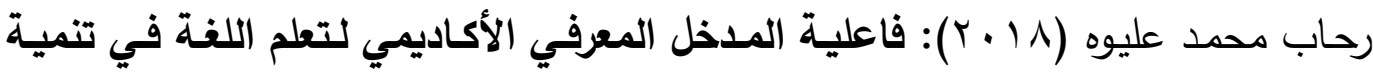
مهارات الطلاقة القرائية وأثرها على مهارات التحدث لاعى تلاميذ المرحلة الإعدادية، رسالة دكتوراه غير منشورة، كلية التربية جامعة بنها.

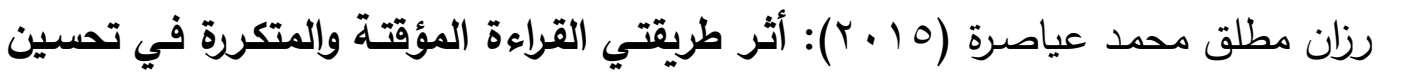

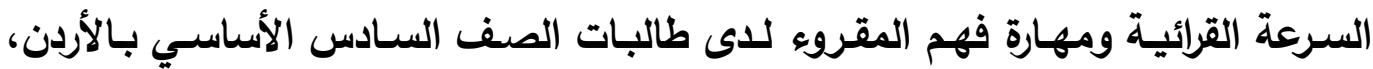
رسالة دكتوراه غير منشورة، كلية التربية، جامعة اليرموك، الأردن.

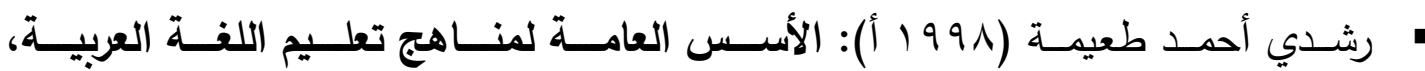

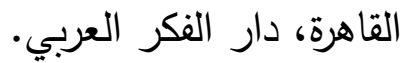
رشدي أحمد طعيمة (991 (191): مناهج تدريس اللغة العربية بالتعليم الأساسي، القاهرة،

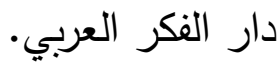
رشدي أحمد طعيمة، محمود كامل الناقة (T + . ب): تعليم اللغة العربية اتصائًا بين المناهج والإستراتيجيات، إيسيسكو، الرباط، منشورات المنظمة الإسلامية للتربية والعلوم والثقافة.

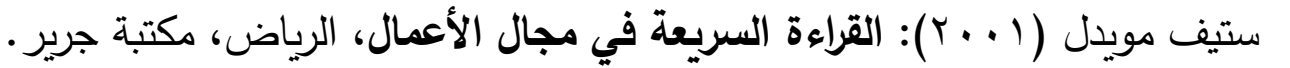

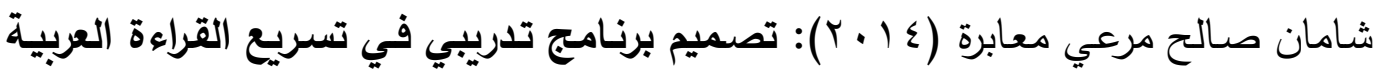

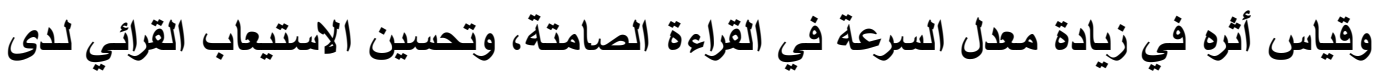

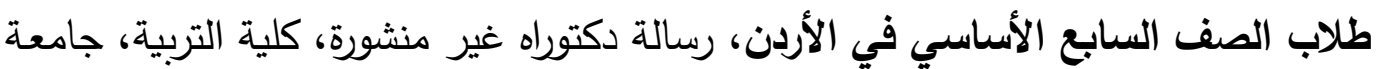

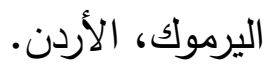

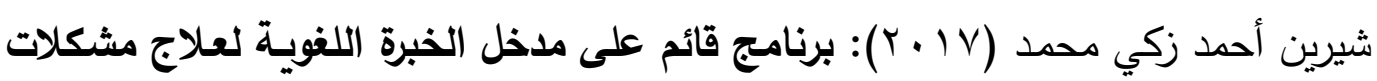

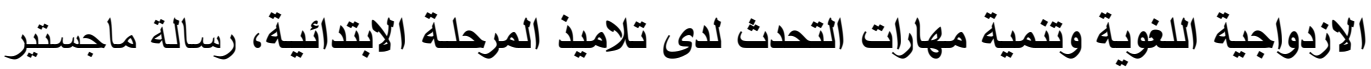
غير منشورة، كلية التربية، جامعة قناة السويس.

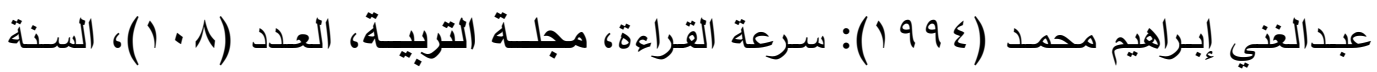

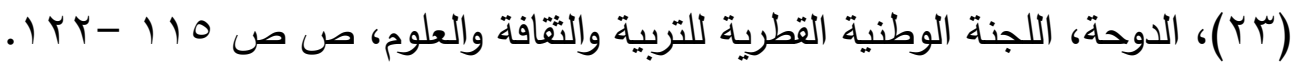




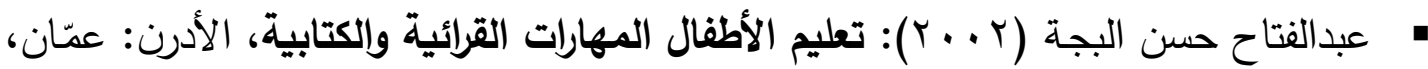

$$
\text { دار الفكر للطباعة والنشر والتوزيع. }
$$

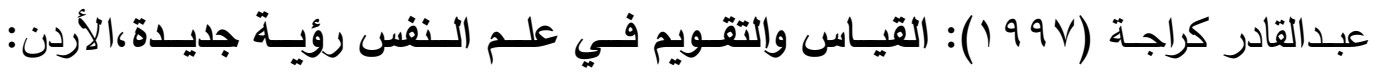

عمّان، دار اليازودي.

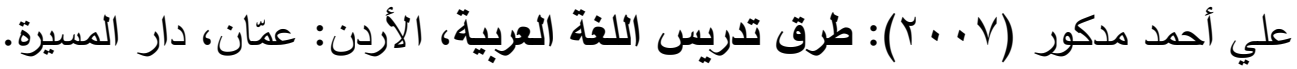

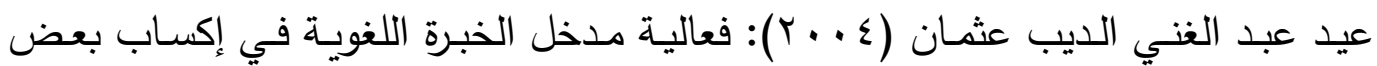
الدفاهيم والاتجاه نحو تعلم موضوعات الدراسات الاجتماعية لدى تلاميذ المرحلة الابتدائية،

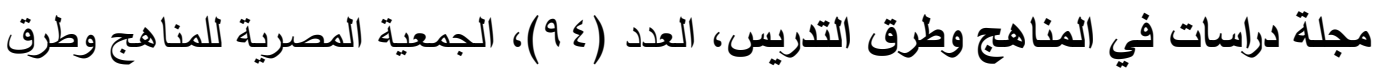

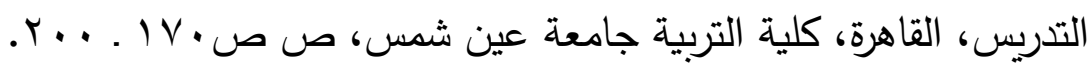

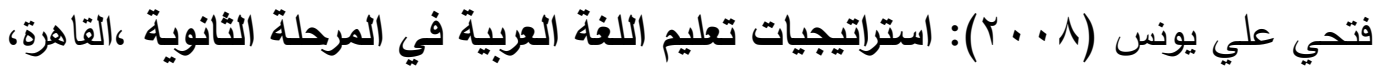
كلية التربية جامعة عين شمس.

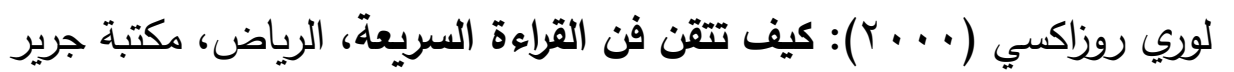

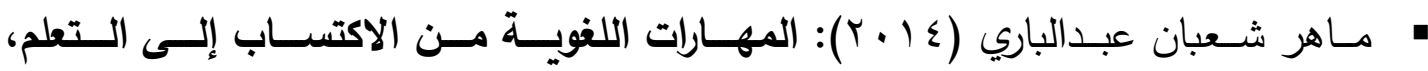
الدمام، مكتبة المتنبي. محمد رجب أحمد (؟ ( ب)): إستراتيجية تعليمية قائمسة على الأنثطة القصصية لتنمية

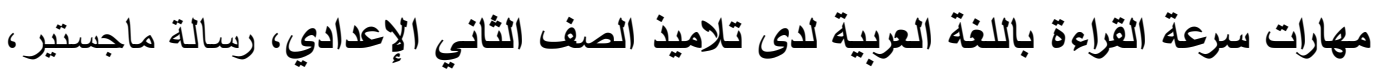
كلية الدراسات العليا، جامعة القاهرة.

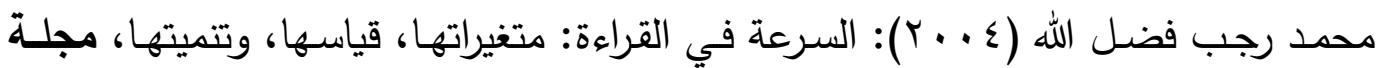

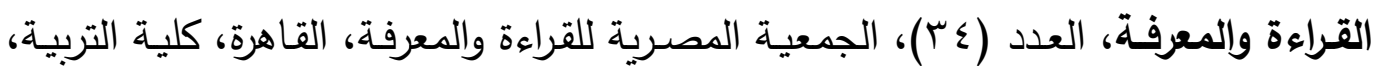

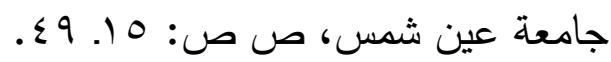

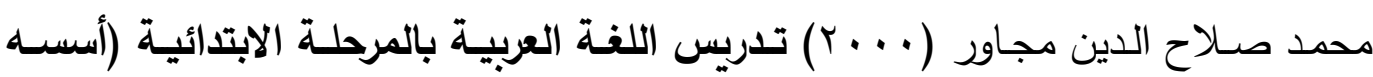

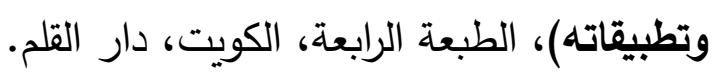

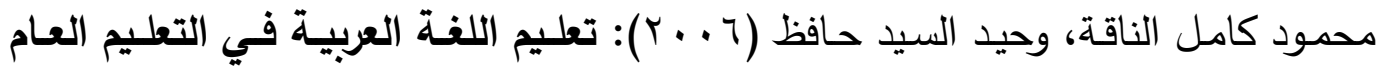

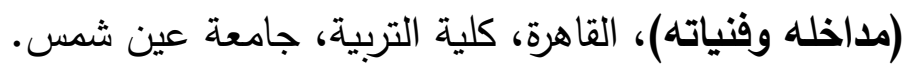

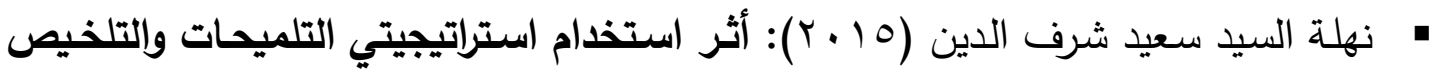
في تنمية بعض مهارات القراءة والكتابة لاى تلاميذ الصف الترائ الرابع الابتدائي، رسالة دكتوراه

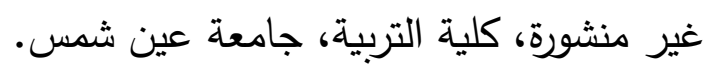

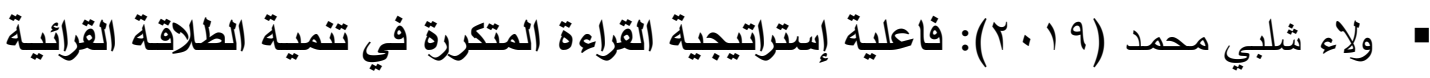
والفهم القرائي لاى تلاميذ المرحلة الابتدائية، رسالة ماجستير غيدية الفراءة منشورة، كلية التربية . جامعة بني سويف. 


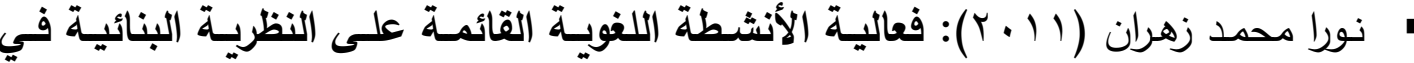
تنمية مهارات الفهم والسرعة في القراءة للى تلاميذ المرحلة الإعدادية، رسالة ماجستير

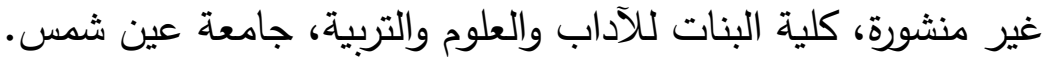

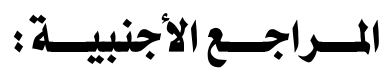

- Aboulfotoh, M.(2013): The effectiveness of the language experience approach in developing EFL reading and writing skills among primary school pupils. Unpublished master thesis,Benha University.

- Allington, R.(1999): Fluency: Avital Key to Comprehension. Instructor , 113 (5) , Pp12:13.

- Angela,G. (2004): The Relationship between Oral reading Fluency Scores and Reading Comprehension Scores ,Unpublished master Thesis, Faculty of the Collage of Education,Universty of Alaska.

- Blau ,L. (2001): 5 surfire strategies for developing reading fluency. Instructor (7), (110).

- Burgess, D. (2003): " Language Experience Approach" Available at: www.csuchico.edu/cme/educ/BIMc281ILEA.html.

- Chang, A.(2012): Improving Reading Rate Activities For Efl Students: Timed Reading And Repeated Oral Reading. Reading in a foreign language, 24 56-83.

- Curran, s. (2007): Using The Language Experience Approach as a part of differentiated literacy instruction, Unpublished master thesis, Hamline University,Saint Paul, Minnesota.

- Dorr, R. (2006): Something old is New Again: Revisiting Language Experience reading teacher , 60 (2), Pp 138-146.

- Duncko, T. (2013):Assessing the Fluency of Automaticity.(Ed), In Rasinski, t \& Padak, N: From Fluency to Comprehension Powerful Instruction reading, New York: The Guilford Press.

- El-Garawany, M. (2010): The effects of repeated reading strategies on developing oral reading fluency and reading comprehension among EFL prospective teachers. Unpublished master thesis, Minufiya University. 
- EL-Mesry, A. (2013): A Suggested Strategy to Develop Libyan Secondary Stage Student's Critical Reading and Writing Skills in the Light of the Language Experience Approach. Unpublished master thesis, ain shams University.

- Gamal, H. (2005): The Effectiveness of using vocabulary autonomous Language learning strategies in improving vocabulary acquisition and Reading comprehension of second year students. Unpublished master Thesis,Institute of educational studies ,Cairo University.

- Hell, M. (1979): teaching Reading as a Language Experience.second Edition, ohio, Charles E. Merrill Public shing Company.

- Husbrouk , J \& Tindal , G.(2006): Oral Reading fluency norms: A valuable Assessment Tool for Reading teacher, The Reading Teacher, 59, (7), Pp (636- 644).

- Miller, J \& Groff, C.(2008): Assessing Reading Fluency. In Kuhn, M \& Schwanenflugel, P, Fluency in the Classroom, New York: The Guilford Press.

- Nessel, D. \& Dixon, N.(2008): Using The Language Experience approach with English language learners, Corwin Press, Thousand Caks.

- Oakly, G. (2005). Reading fluency as an outcome of a repertoire of interactive reading competencies: How to teach it to different types of dysfluent readers (and how ICT can help). New England Reading Association Journal, 41 (1), Pp. 12:21

- Rasinski, T.(2004): Assessing Reading fluency, Honolulu, Hawaii, Pacific Resources for Educationa and Learning. Retrieved: www.prel.orgiproducts/re/assessing-fluency.htm.

- Rasinski, T. \& Padak, N. (2013): From Fluency to Comprehension Powerful Authentic Reading, New York, Guilford Press.

- Taylor, M. (2000): The language experience approach and Adult Learners, Eric Ed350887. 